\title{
Review
}

\section{Environmental Nanoparticles, SARS-CoV-2 Brain Involvement, and Potential Acceleration of Alzheimer's and Parkinson's Diseases in Young Urbanites Exposed to Air Pollution}

\author{
Lilian Calderón-Garcidueñas ${ }^{\mathrm{a}, \mathrm{b}, *}$, Ricardo Torres-Jardón ${ }^{\mathrm{c}}$, Maricela Franco-Lira $^{\mathrm{d}}$, Randy Kulesza ${ }^{\mathrm{e}}$, \\ Angélica González-Maciel ${ }^{\mathrm{f}}$, Rafael Reynoso-Robles ${ }^{\mathrm{f}}$, Rafael Brito-Aguilar ${ }^{\mathrm{b}}$, \\ Berenice García-Arreola $^{\mathrm{b}}$, Paula Revueltas-Ficachi ${ }^{\mathrm{b}}$, Juana Adriana Barrera-Velázquez ${ }^{\mathrm{b}}$, \\ Griselda García-Alonso ${ }^{\mathrm{b}}$, Edgar García-Rojas ${ }^{\mathrm{b}}$, Partha S. Mukherjee ${ }^{\mathrm{g}}$ and Ricardo Delgado-Chávez ${ }^{\mathrm{h}}$ \\ ${ }^{\mathrm{a}}$ The University of Montana, Missoula, MT, USA \\ ${ }^{\mathrm{b}}$ Universidad del Valle de México, México \\ ${ }^{\mathrm{c}}$ Centro de Ciencias de la Atmósfera, Universidad Nacional Autónoma de México, Ciudad de México, México \\ dColegio de Bachilleres Militarizado, "General Mariano Escobedo", Monterrey, N.L., México \\ e Auditory Research Center, Lake Erie College of Osteopathic Medicine, Erie, PA, USA \\ ${ }^{\mathrm{f}}$ Instituto Nacional de Pediatría, México \\ $\mathrm{g}_{\mathrm{g}}$ Interdisciplinary Statistical Research Unit, Indian Statistical Institute, Kolkata, India \\ ${ }^{\mathrm{h}}$ Pathology Consultant, Mexico City, Mexico
}

Accepted 28 August 2020

\begin{abstract}
Alzheimer's and Parkinson's diseases (AD, PD) have a pediatric and young adult onset in Metropolitan Mexico City (MMC). The SARS-CoV-2 neurotropic RNA virus is triggering neurological complications and deep concern regarding acceleration of neuroinflammatory and neurodegenerative processes already in progress. This review, based on our MMC experience, will discuss two major issues: 1) why residents chronically exposed to air pollution are likely to be more susceptible to SARS-CoV-2 systemic and brain effects and 2) why young people with AD and PD already in progress will accelerate neurodegenerative processes. Secondary mental consequences of social distancing and isolation, fear, financial insecurity, violence, poor health support, and lack of understanding of the complex crisis are expected in MMC residents infected or free of SARS-CoV-2. MMC residents with pre-SARS-CoV-2 accumulation of misfolded proteins diagnostic of AD and PD and metal-rich, magnetic nanoparticles damaging key neural organelles are an ideal host for neurotropic SARS-CoV-2 RNA virus invading the body through the same portals damaged by nanoparticles: nasal olfactory epithelium, the gastrointestinal tract, and the alveolar-capillary portal. We urgently need MMC multicenter retrospective-prospective neurological and psychiatric population follow-up and intervention strategies in place in case of acceleration of neurodegenerative processes, increased risk of suicide, and mental disease worsening. Identification of vulnerable populations and continuous effort to lower air pollution ought to be critical steps.
\end{abstract}

Keywords: ACE2, air pollution, Alzheimer's disease, COVID 19, depression, nanoparticles, neurotropism, Parkinson's disease, SARS-CoV-2, suicide

\footnotetext{
*Correspondence to: Professor Lilian Calderón-Garcidueñas, MA, MD, PhD, University of Montana, 32 Campus Drive,
}

287 Skaggs Building, Missoula, MT 59812, USA. E-mail: lilian.calderon-garciduenas@umontana.edu. 


\section{INTRODUCTION}

We are watching with great preoccupation the number of SARS-CoV-2 patients with a wide spectrum of neurological complications, while worsening of cognitive deficits are being recognized in exposed individuals residing in air polluted cities. Neurological manifestations range from the common anosmia and ageusia to encephalopathy, Guillain-Barré syndrome, acute cerebrovascular events resulting in cerebral ischemia, intracerebral hemorrhage, and interestingly ischemic strokes in vascular territories seldom seen on daily practice, i.e., vertebrobasilar system [1-5]. Intriguingly, endotheliopathies and bleeding are described in patients with high morbidity and mortality [1], while patients with delayed recovery of consciousness or severe agitation had bleeding in corpus callosum, internal capsule, and middle cerebellar peduncles attributable to endothelial damage related to viral direct effects or hypoxemia [3]. It is clear SARS-CoV-2 patients exhibit worsening of depression, anxiety, and suicide mortality on one hand $[6,7]$, while researchers are documenting mental health crises in health systems and communities [8]. Mexico's national poverty line included 52.4/127 million Mexicans as of 2018, a number that will be augmented by 10 million as a result in part of the contraction of the economy associated with the COVID-19 global pandemic [9, 10].

Metropolitan Mexico City (MMC) is a 25 million densely populated city with high sustained concentrations of air pollutants, high rates of poverty and marginalization, and limited public health, housing, and public transportation capacity, where violence is epidemic and widespread and depression and suicide are increasing in the middle of the pandemic event [11-15]. Jayaweera et al. [16] have stated about COVID-19 "Airborne transmission is highly virulent and represents the dominant route to spread the disease"; this citation is a serious call to all in MMC, where millions of people live in overcrowding conditions, the slums spreading over large areas with little or no basic services like running water available.

\section{METROPOLITAN MEXICO CITY FINE PARTICULATE MATTER PM M.5 $_{2}$ AND OZONE}

Across the world, in both urban and rural areas, millions of people are exposed to concentrations of $\mathrm{PM}_{2.5}$ above the United States Environmental Protection Agency (USEPA) [17]. Most $\mathrm{PM}_{2.5}$ in urban areas is associated with incomplete internal and external combustion and vehicular traffic, including diesel trucks. High traffic roads close to residencies carry a higher risk of cardiovascular and chronic neurodegenerative diseases, including Alzheimer's disease (AD) [18-28]. Traffic-related air pollution is a major air pollution contributor [29,30], with low-income subjects and minorities at higher risk [31].

MMC is a prime example of traffic-related air pollution [29], and residents are exposed to high ozone and $\mathrm{PM}_{2.5}$ that exceed health limits set forth by the USEPA air quality standards and the World Health Organization (WHO) guidelines [14, 32, 33]. This issue is important because within $\mathrm{PM}_{2.5}$, we find the combustion and friction-derived nanoparticles associated with early and progressive development of AD and myocardial damage [34-42].

Figure 1 shows the concentrations of $\mathrm{PM}_{2.5}$ from 2004 to date in MMC; note $\mathrm{PM}_{2.5}$ has been above current USEPA standards during the entire 16-year period. Zhang et al. [43] discussed airborne transmission of SARS-Cov-2 representing the dominant route to spread the disease. Setti et al. [44] have presented preliminary evidence that SARS-CoV-2 can be deposited on outdoor PM and have suggested that under appropriate conditions of atmospheric stability and elevated levels of outdoor PM, SARS-CoV-2

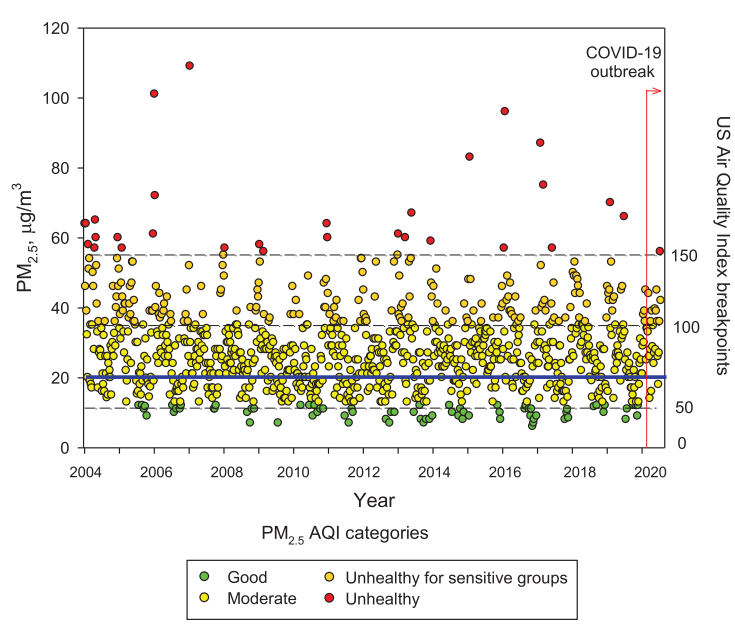

Fig. 1. Trend of maxima $\mathrm{PM}_{2.5}$ 24-h average concentrations registered in monitoring stations of the MMC from January 2004 to May 2020 and their comparison against the WHO daily mean average guideline (blue solid line) and the US AQI categories. Data correspond to measurements from the manual PM network of the SEDEMA under a 6-day sampling schedule, except data from the period March to May 2020 which were obtained from the automatic monitoring network following the same schedule for manual sampling. Source: SEDEMA at: http://www.aire.cdmx.gob.mx/default.php\# 
could be able to create clusters with PM. However, these authors recognize that further studies are needed to confirm that PM might work as a "carrier" for the viral aerosol nuclei when adsorbed on the suspended matter.

Understanding the seriousness of the exposures to air pollutants is key to surveil health consequences. Independent of everyday high $\mathrm{PM}_{2.5}$ exposures, MMC residents are also exposed to frequent meteorological transport of air pollution plumes from regional uncontrolled wildfires $[45,46]$ that bring $\mathrm{PM}_{2.5}$ peaks of hourly averages up to $\geq 200 \mu \mathrm{g} / \mathrm{m}^{3}$. MMC residents are also exposed to high black carbon and organic aerosols (around $10 \%$ and $30 \%$ of the $\mathrm{PM}_{2.5}$, respectively) [47-54].

Unfortunately, little is known about ultrafine and nanoparticles in MMC; research needs to be done to determine if these particles behave like gases, and if they may have the capacity to remain in suspension almost indefinitely. These nano-size particles have the potential of carrying toxic metals, spores, viruses, and bacteria [55]. In MMC, particles with an aerodynamic diameter smaller than $1 \mu \mathrm{m}\left(\mathrm{PM}_{1}\right)$ represent around $75 \%$ of the concentration of $\mathrm{PM}_{2.5}$ [52]. On the other hand, while $\mathrm{PM}_{2.5}$ in urban areas can be directly emitted mainly from combustion sources and formed from complex atmospheric reactions, surface ozone $\left(\mathrm{O}_{3}\right)$ is mainly produced from photochemical reactions involving volatile organic compounds and nitrogen oxides. MMC suffered from very high ozone levels from the late 1980s the early 2000s [56]. However, a weak declining trend for $\mathrm{O}_{3}$ has been observed since 2004, despite several ozone strategy plans implemented by local authorities [57, 58]. Due to the MMC geographical situation, March-May is usually warm, sunny, and rainless, therefore ideal for the chemical production of ozone and other secondary pollutants [56]. Typically ground-level ozone reaches its highest concentrations during these months, leading to the so-called term "MMC ozone season". Figure 2 shows composite trends of maxima $\mathrm{O}_{3} 8$ $\mathrm{h}$ averages for MMC's ozone seasons in 2005, 2010, 2015, and 2020 as indicators of the ozone behavior during the last two decades. Ozone concentrations have been documented above both the WHO guidelines and the USEPA standards for the last 16 years and remain high in the COVID pandemic months (Fig. 2, 2020 panel).

It is worth mentioning that despite strong official restrictions implemented to vehicular traffic in MMC once the COVID-19 was officially declared in the middle of March 2020, neither ozone nor the
$\mathrm{PM}_{2.5}$ levels went down. Unexpectedly, they kept relatively constant, with ozone showing an increase, indicating how complicated the atmospheric chemistry behavior and the strong reactivity of the complex pollutant mixtures in the region. Without question, MMC residents have been exposed to sequential high concentrations of air pollutants-PM and gaseous toxic pollutants-almost every day for the last 20 years [14, 32, 33, 47, 49-52, 56, 59].

\section{NANOPARTICLES ARE CRITICAL FOR BROAD SPECTRUM BRAIN PATHOLOGY AND SARS-COV-2 PENETRATES ALREADY DAMAGED PORTALS OF ENTRY}

The term ultrafine particles applies to airborne particulates of less than $100 \mathrm{~nm}$ in aerodynamic diameter, i.e., diesel exhaust particles, products of cooking, heating, and wood burning [60]. Nano-size particles have different sizes and shapes and can be organic, inorganic, and carbon-based [61]. Metals are a key component associated with nanoparticles (NPs) and Fe-bearing NPs including exhaust emissions (both diesel and gasoline), brake wear, tire and road surface wear, resuspension of roadside dust, underground, train and tram emissions, and aircraft and shipping emissions [18].

NPs are crucial because of their small size, specific physicochemical properties, their protein corona characteristics allowing the immune system to detect them and in the case of metal oxide-based NPs: their magnetic properties [61-66].

Neural and vascular cells are directly and indirectly damaged by NPs and abnormal proteins are evidence of cell damage (Fig. 3). Nanoparticles can travel free in blood and cross any biological barrier, key information to understand their toxicity $[42,61$, 63-69].

Once they cross the alveolar/capillary barrier, nanoparticles are in the major capillary bed in the body and quickly reach the systemic circulation either free in the blood flow or hitchhiking on red or white blood cells [42, 67, 70-72]. Red blood cell transportation of NPs is a very effective way to deliver nanocarriers [73] and along with white blood cells, a key delivery platform to the brain, heart, and gastrointestinal tract [67]. The nasal pathway is also extraordinarily effective and direct to the brain through the olfactory bulb, and since there is an extensive vasculature, access to the systemic circulation is also greatly successful for both NPs and viruses [38, 

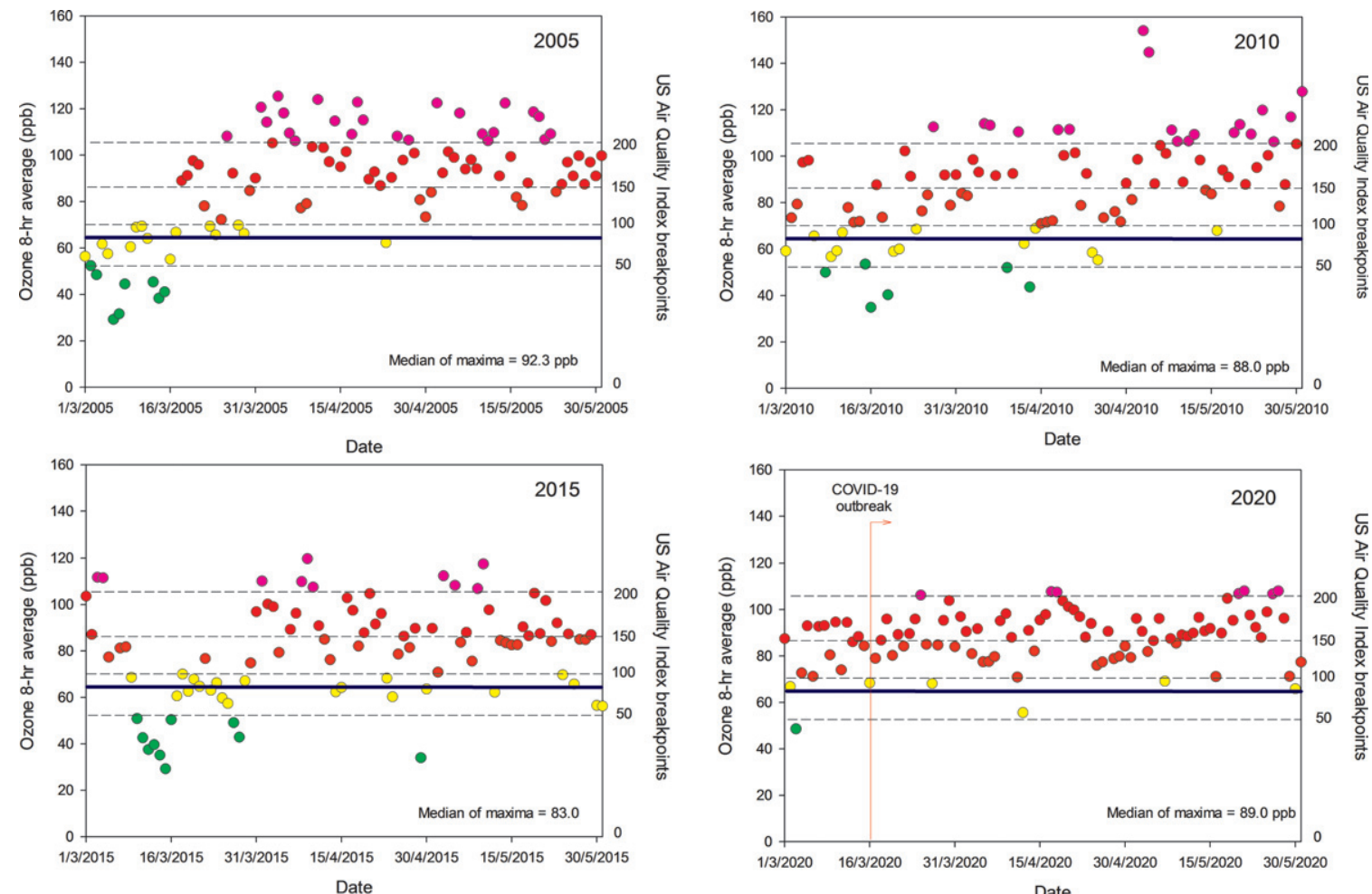

Ozone AQI categories

Good
- Underate
- Unhealthy for sensitive groups
- Very unhealthy

Fig. 2. Trend of daily maxima $\mathrm{O}_{3}$ 8-h average concentrations registered in all monitoring stations of the MMC from March to May, 2005, 2010, 2015, and 2020 and their comparison against the WHO daily mean average guideline (blue solid line) and the US AQI categories. MMC residents are chronically exposed to sustained yearlong high $\mathrm{O}_{3}$ concentrations. Source: SEDEMA at: http://www.aire.cdmx.gob.mx/default.php\#

$71,74,75]$. The nasal portal of entry is critical since it is an early target of NPs damage (young children have extensive olfactory bulb damage), olfaction deficits are early signs of neurodegenerative diseases, including AD and Parkinson's disease (PD) [36, 38, 76-78] and anosmia and ageusia are described in coronavirus infections [79-84]. The trigeminal nerve has to be considered in terms of SARS-CoV-2 ocular involvement [85-87] and certainly plays a key role in the transport of NPs directly to the brainstem: the ophthalmic and maxillary branches are portals of entry and the trigeminal nerve has a few fibers ending in the olfactory bulb [88-91]. The gastrointestinal tract is often ignored as a portal of entry of NPs - we swallow a significant amount of the inhaled NPs-and it is an invasive portal for SARS-CoV-2 [92-94]. MMC residents have already significant small bowel mucosa damage and there is a deep concern SARS$\mathrm{CoV}-2$ could have an easy access to the enteric nervous system $[95,96]$. We have shown NPs reach preganglionic parasympathetic fibers and the vagus nerve, and immunoreactivity of stomach and vagus to phosphorylated $\alpha$-synuclein Ser129 and hyperphosphorylated tau are documented in young MMC urbanites [96]. Lundquist and Artursson's review [92] emphasized two key entry routes for NPs, which are certainly applicable to viruses: the paracellular route via tight junctions and the transcellular transcytosis route.

\section{NANOPARTICLES AND THE SARS-COV-2 DUO HAVE GREAT ADVANTAGES TO DAMAGE THE BRAIN THROUGH THE NEUROVASCULAR UNIT (NVU)}

NVU integrity guarantees the coupling between neural activity and blood flow [97]. Multiple cells 


\section{Nanoparticles and SARS-CoV-2 portals of entry}
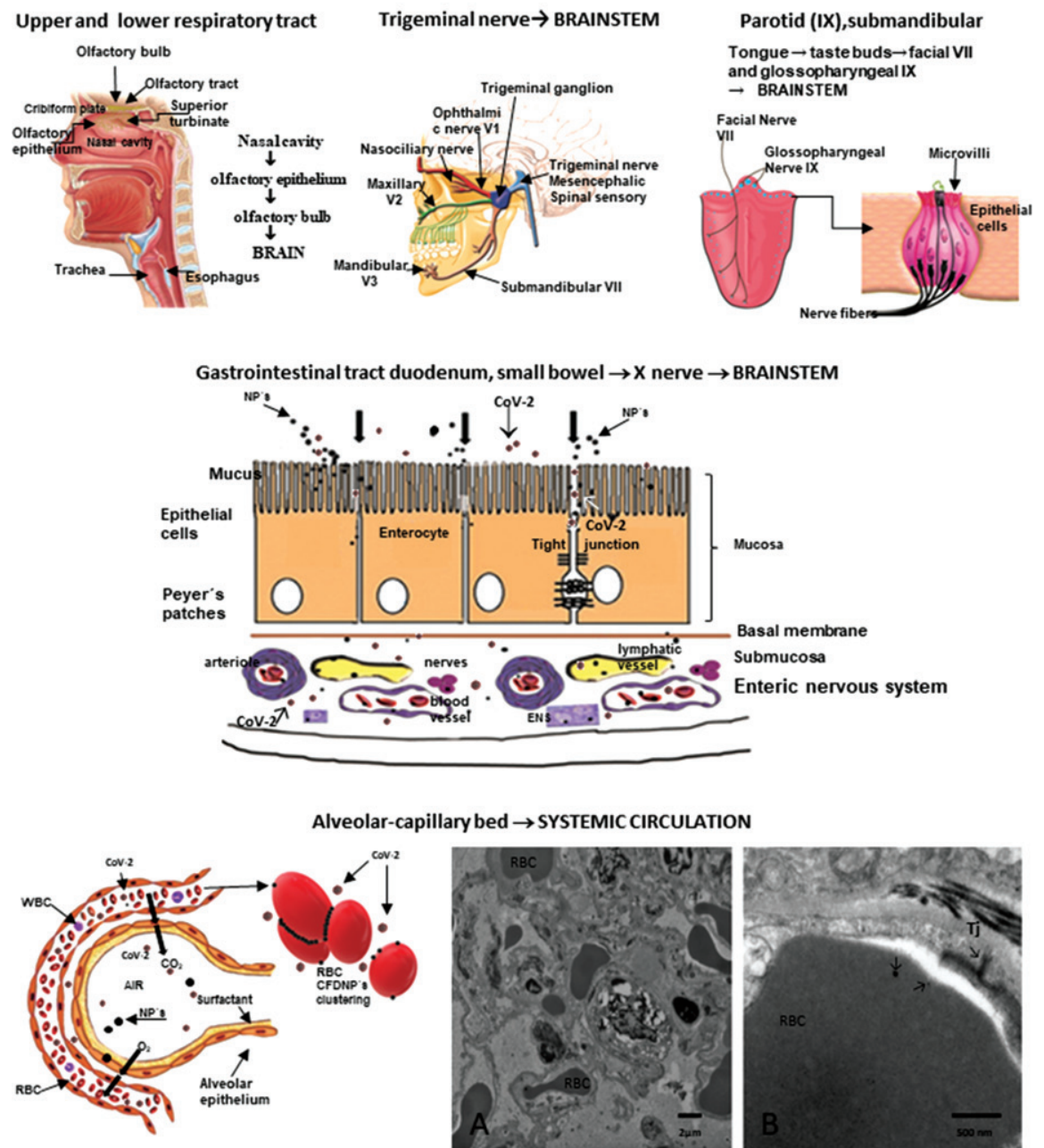

Epithelial and endothelial damage

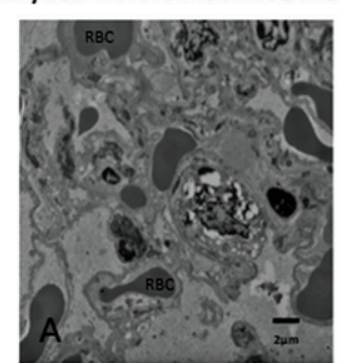

Lung parenchyma

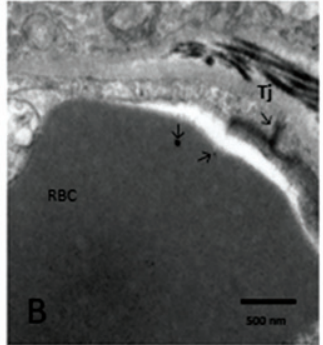

Alveolar-capillary structure and endothelial cell tight junctions (TJs)

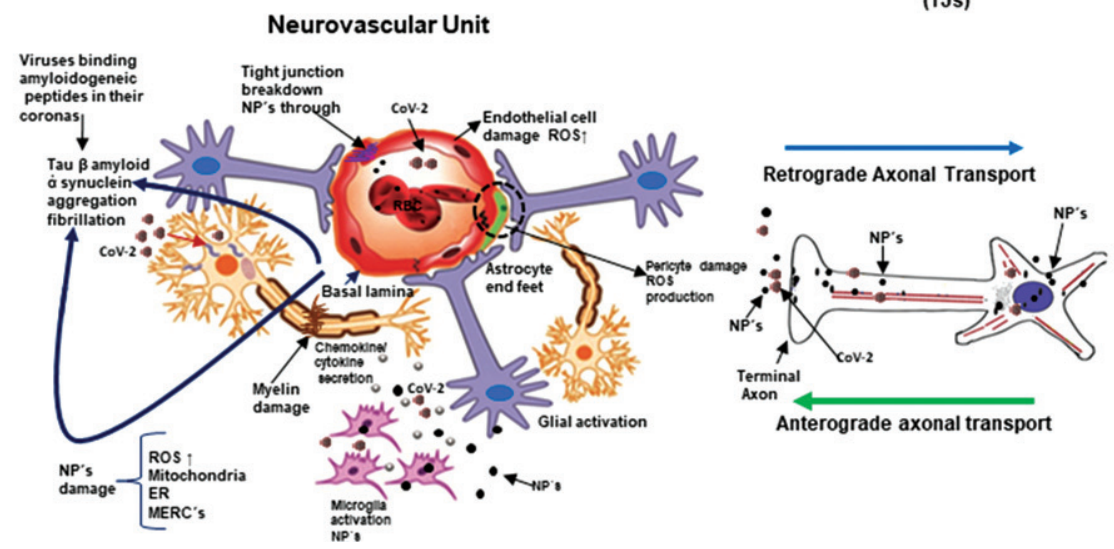

Fig. 3. Nanoparticles and SARS-CoV-2 portals of entry. The different portals of entry shared by nanoparticles and the RNA virus. The electron microscopy of the lung parenchyma in a 23-year-old male non-smoking resident in Mexico City illustrates a common finding: activated endothelial cells in the alveolocapillary barrier and tight junctions loaded with nanoparticles, also seen in red blood cells in close contact with the endothelial cell. 
are engaged in distinct signaling pathways and effector systems across the entire cerebrovascular network already compromised in MMC residents [97, 98]. MMC young residents $\leq 40$ years show NVU abnormalities including 1) endothelial cells (EC) tight junction abnormalities with NPs deposition; 2) EC, pericytes, and smooth muscle cells with abnormal mitochondria and endoplasmic reticulum with numerous NPs; 3) passage of NPs from the capillary wall to the neural spaces, and 4) expansion of the Virchow spaces with breakdown of the perivascular neuropil and leaking of serum and red and white blood cells. Every NVU component is compromised, and mitochondria, mitochondriaassociated endoplasmic reticulum, and mitochondrial matrix and cristae are targets of NPs. Abnormal generation of reactive oxygen species, mitochondrial dysfunction, and altered mitochondrial quality control are the direct result of NVU damage [99-109]. The NP biomolecular corona, the result of the adsorption of biomolecules on the NP surface, ultimately determines the NVU and neural cells severity damage [110-114]. Thus, the NVU damage will impact at least in part, the capacity of SARS-CoV-2 to invade neural tissues and extend throughout the brain. Understanding of protein function following particle and virus binding is necessary to properly evaluate pathophysiological events [112, 115-117]. Viruses, i.e., respiratory syncytial virus and herpes simplex virus type 1 (HSV-1), can make protein coronas, information relevant to Parkinson's disease (PD), influenza, and now SARS-CoV-2. Ezzat and coworkers emphasized a critical piece of information: viruses share many biophysical properties with NPs. The authors discussed respiratory syncytial virus and HSV-1 as capable of accumulating distinctive protein coronas in different biological fluids and corona pre-coating differentially affecting viral infectivity and immune cell activation. Moreover, authors demonstrated that viruses bind amyloidogenic peptides in their corona and catalyze amyloid formation via surfaceassisted heterogeneous nucleation. Also, key for this review, Berardi et al. [118] discussed non-sticky viral NPs are capable of crossing most nonspecific protein and glycoprotein barriers encountered, when administered through mucosal and non-mucosal routes.

The endothelium is a critical barrier and damage by both NPs and viruses will alter the regulation of molecular and cellular traffic across this barrier [119]. SARS-CoV-2 direct and indirect endothelial damage certainly contributes to mortality $[120,121]$ through diverse mechanisms, endothelial dysfunction, production of extracellular vesicles and thromboembolism, oxidative stress, dysregulated immune responses, abnormal coagulation, and hypoxia [122, 123]. Lymphocytic vasculitis with EC swelling, fibrinoid necrosis, and thrombosis, along with viral particles in endothelium are described in children's skin chilblain biopsies with clinical purpura [124]. Damage to the myocardium and bowel are also related to microvascular thrombosis and diffuse EC injury [125, 126]. EC damage contributes significantly to multiple organ failure.

Thus, NVU damage predicts brain dysfunction and neurodegeneration and SARS-CoV-2 could use a damaged NVU to facilitate neural invasion and extent the damage further. The biologically plausible association between nanoparticles and viral protein coronas will impact viral infectivity and immune cell activation. Viruses bind amyloidogenic peptides in their corona and catalyze amyloid formation via surface-assisted heterogeneous nucleation. Initiation of amyloid formation could have devastating consequences in highly exposed air pollution populations.

\section{NEUROINFLAMMATION, NANOPARTICLES, AND SARS-COV-2}

Nanoparticles per se induce neuroinflammation [64, 127-131]. Titanium dioxide NPs induced an agedependent modulation of blood-brain barrier integrity associated with interleukin- $1 \beta$ and interferon- $\gamma$ increases in aging rats' brain [127]. Diesel exhaust NPs produced olfactory bulb and hippocampal oxidative stress and inflammatory responses in adult mice in conjunction with anxiety and depression [128]. Strikingly, there is evidence exposure to metal and metal oxide NPs, such as $\mathrm{Fe}_{2} \mathrm{O}_{3}, \mathrm{CuO}$, and $\mathrm{ZnO}$, plays a potential role in the pathophysiology of neurodegenerative diseases such as AD through neuroinflammation [131]. A low dose of $\mathrm{CuO}$ NPs activates the $\mathrm{NF} \kappa \mathrm{B}$ signaling pathway and increases amyloid- $\beta$ protein precursor (A $\beta P P)$ expression, a pathway directly related to $A \beta$ amyloidosis, a hallmark of $\mathrm{AD}$ [131]. Portals of entry such as the tongue constitute a direct pathway to the brain and neuroinflammation via the taste nerve translocation pathway (VII and IX cranial nerves) as described using $\mathrm{ZnO}$ and TiO2 NPs [129, 132]. Binding of NPs to activated endothelial cells, astrocytic feet and choroid plexus damage the NVU and the blood-cerebrospinal 
fluid barrier contributing to the inflammatory process [133-136].

It is important to remember that NPs have endothelial cells as first line targets and ubiquitous particles such as zinc oxide nanoparticles very efficiently reduced the continuity of tight junction proteins claudin-5 and zonula occludens-1 (ZO-1) at the cell junctions [136]. ZnO NPs induced adherens junction protein VE-cadherin internalization from membrane to cytosol and dissociation with $\beta$-catenin, leading to reduced and diffused staining of VE-cadherin and $\beta$ catenin at cell junctions. Chen et al. [136] discussed how disrupted tight and adherens junctions lead to inflammatory cellular infiltrates.

Neuroinflammation plays a central role in the pathogenesis of $\mathrm{AD}$ along mitochondrial dysfunction, excitotoxicity, abnormal innate immunity, and the activation of inflammasomes and microglia [137-146]. Mexico City subjects exhibit neuroinflammation, as measured by upregulation of genes, very soon after birth followed by increased neuroinflammation associated with progression of $\mathrm{AD}$ [20, $22,34,35,37,38,137]$. Neuroinflammation is an intrinsic part of $\mathrm{AD}$, thus activation of astrocytes and microglia, neuronal and glia death, and upregulation of proinflammatory and anti-inflammatory cytokines, chemokines, and inflammasomes are expected [141, 145, 147-157]. Chronic inflammation, a dysfunctional immune system, and the onset and progression of AD go hand in hand [149, 154].

Parkinson's disease (PD) shares with AD the neuroinflammation and immunologic central and peripheral responses key to a-synuclein pathology [59, 158-165]. Lewy neurites are detected in the olfactory bulb and brainstem of MMC children and teens concomitantly with the AD neuropathological hallmarks [38].

Coronaviruses invade, replicate, and proliferate in neural cell lines and inflammation is a well know mechanism of their neural devastation [74, 166-175]. Coronaviruses are lipid enveloped and spherical viruses in the nanosize range $100-120 \mathrm{~nm}$. The nucleocapsid contains a single-stranded non-segmented positive-sense RNA genome [176]. The name Coronavirus comes from the crown-like appearance of the virus-large petal-shaped spikes protruding from the envelope-the spike glycoprotein, 20-40 nm long. The $\mathrm{M}$ protein is the most abundant protein and provides structural support, while the E protein is a small membrane protein essential for the assembly and release of virions [176]. Specific chemotactic cytokines such as Chemokines CXCL10 (interferon- inducible protein $10 \mathrm{kDa}$ ) and CXCR2 play a role in host defense and give rise to demyelination and neurodegeneration, both well documented in Coronavirus models of acute encephalomyelitis [177-181]. Host inflammatory responses activate $\mathrm{T}$ and $\mathrm{B}$ lymphocytes expressing CXC chemokine receptor 3 (CXCR3) and in turn determine the persistence of the virus in white matter tracts, chronic neuroinflammation, and demyelination [180]. Coronaviruses recognize host receptors via spike glycoprotein ( $\mathrm{S}$ protein, with a key role in receptor (ACE2) binding and virus entry) and other proteins, including Orf 3 , Orf 8 , and Orf 10 , invade host cells by membrane fusion, replicate through large replicationtranscription complexes, and increase proliferation by interfering, modulating and suppressing the immune response in the host $[174,182]$. The presence of furin-like cleavage site in SARS-CoV-2 facilitates the $S$ protein priming and could increase the spread efficiency of SARS-CoV-2 [183]. An extended structural loop containing basic amino acids at the interface of the receptor binding (S1) and fusion (S2) domains was identified by Jaimes et al. [184]. The authors suggested this loop could be a key component in the evolution of SARS-CoV-2, affecting virus stability and transmission [184]. The presence of point mutations in the spike glycoprotein ( $\left.\mathrm{rOC} / \mathrm{U}_{\mathrm{s} 183-241}\right)$ increases the neurovirulence in mice and induces cell death in murine and human neuronal cells [185]. Meessen-Pinard and coworkers [185] emphasized that as necroptosis disrupts cellular membranes and allows the release of damage-associated molecular patterns, the cascade of proinflammatory cytokines may represent a proinflammatory cell death mechanism that contributes to excessive neuroinflammation and neurodegeneration and eventually to neurological disorders after a coronavirus infection.

Twenty years ago, the discovery of angiotensinconverting enzyme (ACE2), a zinc metallopeptidase able to hydrolyze Ang I to Ang 1-9 and Ang II to Ang 1-7, marked the critical role of the enzyme as a negative regulator of the renin-angiotensin system and later, as a SARS-CoV-2 receptor (the major spike glycoprotein $\mathrm{S} 1$ binds to the $\mathrm{N}$-terminal region of ACE2) [174, 186, 187]. The issue of SARSCoV-2 binding to its receptor ACE2 is of utmost importance for residents in polluted environments [188-196]. Briefly, ACE2 is extensively present in the brain in areas associated with cardiovascular function, specifically the area postrema, dorsal motor nucleus of the vagus, nucleus of tractus solitarius, nucleus ambiguous; primary motor cortex, frontal 
cortex, and numerous other nuclei extending from the cerebral cortex [197-202]. In the excellent ACE2 review by Gheblawi et al. [194], the authors made it clear that the balance of the renin-angiotensin system (RAS) is vital and that loss or gain of function are involved in heart failure, systemic and pulmonary hypertension, myocardial infarction, and cardiovascular disease complications of metabolic diseases. The cell invasion of SARS-CoV-2 is facilitated by the interaction between the spike glycoprotein $\mathrm{S} 1$ with the extracellular domains of the ACE2 transmembrane proteins, followed by downregulation of surface ACE2 expression [194]. Since both Sproteins and ACE2 are proteolytically modified in the process, the baseline host cell proteases including transmembrane serine protease 2 are key for virulence [203]. The depletion of ACE2 is important in the pathogenesis of SARS-CoV-2 because the virus is endocytosed by cells in conjunction with ACE2. ADAM-17, a type 1 transmembrane Zndependent metalloprotease, comes to play because it also mediates proteolysis and ectodomain shedding of ACE2. Upregulation of ADAM 17 is a key factor in inflammation associated with heart failure and coronary artery disease [204]. Of deep interest for MMC residents, ADAM17 is also involved in neuroinflammation through the cleavage of $\mathrm{TNF} \alpha$ and interleukin-6 receptor [205], two key proinflammatory cytokines upregulated in young MMC urbanites' brain [22, 35]. SARS-CoV-2 gives rise to an imbalance of Th17/Treg cell function, overactivation of immune cells, a proinflammatory cytokine storm enhancing the RAS imbalance, and the loss of ACE2 resulting in severe inflammation [194]. Strikingly, ACE2 expression is reduced in specific brain areas (i.e., area postrema, dorsal motor nucleus of the vagus) in animal models with hypertension and heart failure [201]. On the other hand, ACE2 inhibition elevates blood pressure and increase the sympathetic cardiac tone. Thus, autonomic mechanisms play a key role in the impact of ACE2 as a negative regulator of the renin-angiotensin system [206]. Indeed, SARSCoV-2 may downregulate ACE2, which increase Angiotensin II with detrimental consequences [207].

Of deep concern is the capability of SARS-CoV2 to reach the brain using the systemic circulation and the endothelium of the brain capillaries [191, 208] given that aging per se decreases ACE2 and results in oxidative stress and endothelial dysfunction in cerebral arteries-a scenario present in MMC young residents in relation to exposure to $\mathrm{PM}_{2.5}$ and combustion and friction-associated nanoparti- cles [39]. The review by Baig et al. [209] shows pathways facilitating the brain invasion: the interaction with ACE2 receptors in cerebral capillaries would be an ideal portal of entry, followed by direct entrance through the olfactory bulb. Other pathways facilitating neural invasion include SARS-CoV-2 receptor ACE2 exploiting species-specific interferondriven upregulation of ACE2 [210] and upregulation of transmembrane serine protease 2 , an androgenresponsive protease that cleaves SARS-CoV-2 spike protein [211].

Chronic neuroinflammation and a dysfunctional immune system go hand in hand with the onset and progression of $\mathrm{AD}$ and $\mathrm{PD}$ in young urbanites exposed to air pollutants. Both nanoparticles and SARS-CoV-2 produce neuroinflammation and use the same portals of entry. The downregulation of ACE2 resulting in oxidative stress and endothelial dysfunction likely contribute to the SARS-CoV-2 neuroinflammatory capabilities. An extensive neuroinflammatory and neurodegenerative process with an abnormal neurovascular unit set the optimal conditions for SARS-CoV-2 brain invasion.

\section{SARS-COV-2 AND THE RENIN ANGIOTENSIN SYSTEM}

The role of the central RAS in the pathophysiology of neurological and psychiatric diseases including $\mathrm{AD}$ and $\mathrm{PD}$ has been discussed by a number of researchers across the world [202, 212-225]. A key issue is the use of drugs acting via the reninangiotensin system in the prevention and treatment of AD. Kehoe et al. (2016) and Walker et al. (2020) described the significant reduction of ACE2 in patients with $\mathrm{AD}$ and the inverse correlation with $\mathrm{A} \beta$ and $\mathrm{p}$-tau, the two prime neuropathological markers of $\mathrm{AD}[202,226]$. They also showed in AD patients the reduction of the ratio Ang II to Ang 1-7, as a proxy for ACE2 activity. The RAS system impacts blood pressure, cerebral blood flow, neuroinflammation, and oxidative stress. On the one hand, Angiotensin (Ang) II, via angiotensin type 1 receptors promote brain tissue damage, while Ang-1-7 seems to elicit neuroprotection [220]. RAS-targeting drugs as ACE inhibitors and angiotensin receptor blockers seem to exert beneficial effects on AD [220, 222-224, 227].

Evans et al. [225] have shown that increased brain ACE2 activity, a major effector of rRAS, by intraperitoneal administration of an activator of ACE2, lowered hippocampal $A \beta$ and restored 
cognition in mid-aged (13-14-month-old) symptomatic $\operatorname{Tg} 2576$ mice. The authors concluded that "ACE2 enhancement protects against and reverses amyloid-related hippocampal pathology and cognitive impairment in a preclinical model of AD" [225]. Wright and Harding [218] summarized in a highly recommended review paper how an unbalanced RAS system contributes to "neuroinflammation, oxidative stress, reduced cerebral blood flow, tissue remodeling, and disruption of memory consolidation and retrieval." We fully agreed with Verdecchia et al. [228] and Perrota and co-workers [229] that RAS is a double-edged sword in the SARS-CoV-2 world. On one hand, the ACE2 upregulation suggest a potential role against lung damage in SARS-CoV-2 infected patients. On the other hand, the controversy sets on risk of increase susceptibility to infection linked to ACE2 upregulation associated with RAS inhibitors. At this time, however, a number of Cardiology, Hypertension and Pharmacology Societies strongly recommend against ACE inhibitors or angiotensin receptor blocker drugs discontinuation in patients with COVID 19. We agreed with Barilla et al. [230] on their statement: "Their discontinuation can increase Ang II activity and induce injury to the lungs or cardiovascular system."

The issue of particulate matter and increased susceptibility to SARS-CoV-2 is raised in the relationship between $\mathrm{PM}_{2.5}$ concentrations and incidence, mortality rate and case fatality risk of COVID-19 by Borro et al. [231]. One hundred and ten Italian provinces were categorized by $\mathrm{PM}_{2.5}$ concentrations and differential SARS-CoV-2 spread in the period 20 February-31 March 2020. Strikingly, bioinformatic analysis of the DNA sequence encoding the SARS-CoV-2 cell receptor ACE2 identified positive correlations between $\mathrm{PM}_{2.5}$ levels and the incidence $(r=0.67)$, mortality rate $(r=0.65)$, and death rate $(r=0.7)$ through nine putative consensus motifs for the aryl hydrocarbon receptor. The hypothesis that pollution-induced over-expression of ACE2 on human airways may favor SARS-CoV-2 infectivity is in place in this Italian study. Wu and co-workers [232] in a preprint USA work (as of August 21, 2020), covering 3,000 counties up to April 22, 2020 found that an increase of $\mathrm{PM}_{2.5}$ of $1 \mu \mathrm{g} / \mathrm{m}^{3}$ was associated with $8 \%$ increase in COVID-19 death rate. This is not an unexpected result in view of Borro et al.'s work [231] and brings to public light the absolute need to control $\mathrm{PM}_{2.5}$.

Tobacco smokers [233, 234] are exposed to high $\mathrm{PM}_{2.5}$ concentrations and tobacco or marijuana smoke and vaping exposures trigger the expansion of goblet cells with a concomitant increase in ACE2 expression. Smokers should be considered high risk for SARS-Cov-2 especially if they already have chronic obstructive pulmonary disease [235]. Usman et al. [236] wrote about the controversial issues related to smoking: the claims of protective effects (i.e., the anti-inflammatory effect of nicotine) versus the extensive respiratory damage directly related to smoking and worsening the response to COVID infections.

\section{NEUROLOGICAL MANIFESTATIONS OF COVID 19 AND NEURODEGENERATION}

The list of neurological manifestations keeps growing, with anosmia and ageusia on top of the list [5, 79-83, 237, 238-240]. The long-term development of neurological and neurodegenerative disorders is of deep concern for a number of researchers [7, 241-243]. PD is certainly a possibility since viruses, i.e., $\mathrm{H} 1 \mathrm{~N} 1$ replicate in neuronal cells and could induce seeds of aggregated $\alpha$-synuclein, key factors in the pathogenesis of synucleinopathies [244]. Marreiros and co-workers [244] support the concept of aberrant proteostasis induced by viruses is an underappreciated factor in initiating protein misfolding. We absolutely agreed with Naughton et al. [245] on their statement "Immune response and excessive inflammation in COVID-19 may also accelerate the progression of brain inflammatory neurodegeneration", and their inclusion of high risk for diabetic patients, African-Americans, and Hispanics is warranted. Heneka et al. [246, 247] and Ising et al. [139] discussed a key inflammation player that is very relevant for SARS-CoV-2 patients: the NLRP3 inflammasome-mediated inflammation inducing or aggravating neurodegenerative processes that lead to functional impairment in $\mathrm{AD}$.

There is no question the viral neurotropism is important along factors intrinsic to the host, including genetics, innate immunity, the hyperactivation of the immune system, and the development of cytokine storm syndrome along with the immune previous status of the host to the COVID-19 encounter [75, 195, 248-250]. Thus, the approach suggested by Winkler et al. [251] with the Global COVID-19 Neuro Research Coalition and the work of Ferrarese and coworkers [252] about establishing a retrospective and prospective observational study aimed to detect neurological manifestations of COVID-19 will yield 
an enormous opportunity to define in targeted populations the range of neurological manifestations and the associated risk factors. Long-term neurodegenerative diseases ought to be in the mind of every neurologist across the world, with aberrant proteostasis, neuroinflammation, and abnormal immune responses being key factors for accelerating AD and PD pathology.

\section{PSYCHIATRIC DEMANDS, SUICIDE, AND COVID-19}

There is no doubt in the minds of physicians and health workers across the globe of the multiple factors associated to the pandemic playing a decisive role in the mental health of millions of people. Problems ranging from massive unemployment, contraction of labor market, economic insecurity, domestic violence, uncertainty, and social isolation have a detrimental impact on mental health. It is also clear that some people are more vulnerable than others, including patients surviving severe COVID19 disease, patients with pre-COVID serious mental illness, and those with alcohol use disorder and alcohol-associated liver disease may be among the most severely impacted [6, 253-261].

There are three scenarios of deep concern in terms of psychiatric support at this time:

1) Psychiatric manifestations such as depression related directly to virus impacting the brain of exposed subjects. Lyons and co-workers [262] discussed the possibility of literally having a tsunami of post-viral depression, a biological plausible scenario knowing the neurotropic features of SARS-CoV-2.

2) The relationship between peripheral inflammatory markers in COVID-19 patients and higher levels of depression $(p<0.001)$, anxiety $(p<0.001)$, and post-traumatic stress symptoms $(p<0.001)$ discussed in the work of Guo et al. [263].

3) MMC residents with symptomatic or asymptomatic COVID-19 are fully expected to accelerate their progression of $\mathrm{AD}$ and $\mathrm{PD}$, based on their synergistic systemic and neuroinflammatory increases related to the virus itself and the ongoing air pollution related process. Children, young adults, and the elderly could present with progression of pre-existing or increased neuropsychological pathological outcomes [264-266].
Suicide ought to be a significant concern in patients exposed to SARS-CoV-2 [261]. McIntyre and Lee [253] have discussed preventing suicide in the context of the COVID-19 is a critical public health priority. It is also a priority to identify the most vulnerable populations. We discussed patients with serious mental problems and persons experiencing features of posttraumatic stress disorder or drug/alcohol abuse are at higher risk.

MMC subjects carrying an Apolipoprotein 4 allele have a higher risk of suicide in the pre-COVID era, i.e., 4.92 times higher suicide odds versus APOE3, and strikingly, 23.6 times higher odds of NFT V $(p<0.0001)$ (acceleration of the AD staging) versus APOE4 non-carriers-obligating us for identification of this high-risk population [37]. In Mexico, suicide is linked to unemployment [267]. Wang and coworkers [267] performed an analysis of suicides in Mexico in the period 1981-2016 and it was clear there was a positive bidirectional causality between suicide rate and the unemployment rate in the preCOVID19 period. In the 18 months pre-COVID era, we already had a major reduction of Mexico's growth, now projected as minus $10.5 \%$ in 2020 according to the International Monetary Fund [268]. According to the International Monetary Fund for economies struggling to control infection rates (i.e., Mexico), a lengthier lockdown will inflict an additional toll on economic activity. As discussed by Valeria Moy, the "country's ability to grow in the future is being destroyed, bit by bit, mostly unperceived" [269]. Mexico economic performance added to the COVID19 crisis will result in a significant increment in the number of suicides $[11,12]$, especially in the hardhit cities, those with a great number of unemployed, poor people, without access to health care. Health crisis built on economic disasters result in serious health impacts. Suicide is one consequence of this complex crisis and identifying the vulnerable populations and helping them, should be a key health priority.

\section{SUMMARY OF THE PROPOSED CASCADE OF PATHOLOGICAL EVENTS IN METROPOLITAN MEXICO CITY RESIDENTS}

The starting point is the fact that SARS-CoV-2 is a neurotropic virus, capable of accessing the CNS through the same portals of entry documented for combustion and friction associated NPs [39]. These 
pathways include: the nasal olfactory epithelium with a direct access to the olfactory bulb and the trigeminal (V), facial (VII), and glossopharyngeal (IX) nerves, and each of these providing direct access to the brainstem. Thus, the nasal, ocular, salivary glands, and tongue are effective portals for SARS-CoV-2 and the access to the brain is direct. All sites are indeed effective transmission sites and portals of entry of NPs [270-274].

The gastrointestinal tract is also very effective portal of entry for both NPs and SARS-CoV-2. MMC young residents have duodenal barrier damage and autoimmune responses to tight junctions and neural proteins [95]. The intestinal breakdown barrier has an impact on the neuroenteric system, the vagus, and the brainstem [36, 96]. Trans-synaptic transmission of NPs or viruses reaching preganglionic parasympathetic vagus motor neurons is a plausible biological pathway to reach the brain. Changes in microbiota composition, increased permeability of the gut barrier, and immune activation leading to systemic inflammation, which in turn may impair the bloodbrain barrier and promote neuroinflammation, neural injury, and ultimately neurodegeneration [275-285]. Millions of people are being exposed to many common consumer products with NPs, including food additives/supplements and packaging materials in contact with foods [92, 286-290]. The direct effects of NPs upon the gut microbiome and the changes in the intestinal barrier supportive of bacterial changes are well known [91, 291-296].

SARS-CoV-2 ACE2 is highly expressed on differentiated enterocytes as shown in human small intestinal organoids [297], and indeed Venkatakrishnan and coworkers [298] have discussed the gut as the "putative hotspot of COVID-19, where a maturation correlated transcriptional signature is shared in small intestine enterocytes among coronavirus receptors (ACE2, DPP4, ANPEP)."

MMC residents have a disrupted intestinal barrier related to NPs and thus are at higher risk of quick intestinal invasion with all detrimental consequences [43, 299-301], including persistent viral shedding in feces, a serious problem in a country where fecal contamination in the urban environment due to inadequate sanitation is common, running water to wash peoples' hands is scarce, and where public schools do not have readily available water on school grounds. Deeply worrisome is the presence of SARS-COV-2 RNA on $\mathrm{PM}_{10}$ collected in Northern Italy supporting the virus can create clusters with PM [44] and thus PM is a Trojan horse for the virus. The presence of
SARS-CoV-2 in sewage thus is indeed not a surprise [302] and complicates things for MMC residents getting their vegetables from areas using sewage water [303].

The alveolar-capillary bed is a target of SARS$\mathrm{CoV}-2$. Diffuse alveolar damage is characterized by intra-alveolar edema, fibrin deposition, hyaline membranes, and interstitial inflammation, followed by Type II pneumocyte proliferation, focal hemorrhage, granulation tissue formation, and collagen deposition [304]. The lung pathology associated with NPs depends on the chemical composition, dose, and host responses [305]. Experimentally, $\mathrm{Fe}_{2} \mathrm{O}_{3} \mathrm{NPs}$ and AgNPs cause significant DNA base oxidation as indicated by the elevated DNA content of 8-hydroxy$2^{-}$deoxyguanosine in the heart and lungs. Moreover, significant decrease in antioxidant enzymes, total antioxidant capacity, and reduced glutathione in heart and lung are striking. A dose-dependent increase in production of TNF- $\alpha$ and IL- 6 are seen along with synergistic effects if more than one type of NP is administered [305, 306].

MMC residents showed significant oxidative damage, rupture of the alveolo-capillary barrier with passage of NPs through the barrier and pick up of NPs by intracapillary macrophages [307]. Interestingly, the lungs even in small children have ample anthracosis patches on the pleural surfaces. These children were from households with no history of smoking [307]. Once the NPs go to the systemic circulation, either free or in red or white blood cells, their journey can take them to the brain. The alterations seen in Fig. 4 include enlargement of the Virchow space, breakdown of the EC cell junctions, and NPs traversing the NVU barrier. Axonal transport of NPs can be retrograde and through synapsis, all documented in MMC residents.

SARS-CoV-2 arrives to MMC residents that have opened barriers for easy access to the brain. Figure 4 shows electron microscopic pictures with the typical lesions in $\leq 40$ year old MMC subjects. The extensive NVU and nasal and olfactory bulb damage and the hallmarks of AD and PD are seen in childhood and progress as the subject ages in MMC. SARS-CoV2 takes advantage of the endothelial activation and the organelle damage and the opening capillary gaps to the neural space. Brain hemorrhages and strokes likely relate to the baseline host vascular damage and expectedly, subjects with morbidities such as hypertension, will have the highest risk for brain acute involvement. ACE2 status would be critical here since the depletion of ACE2 is key in the pathogenesis of 

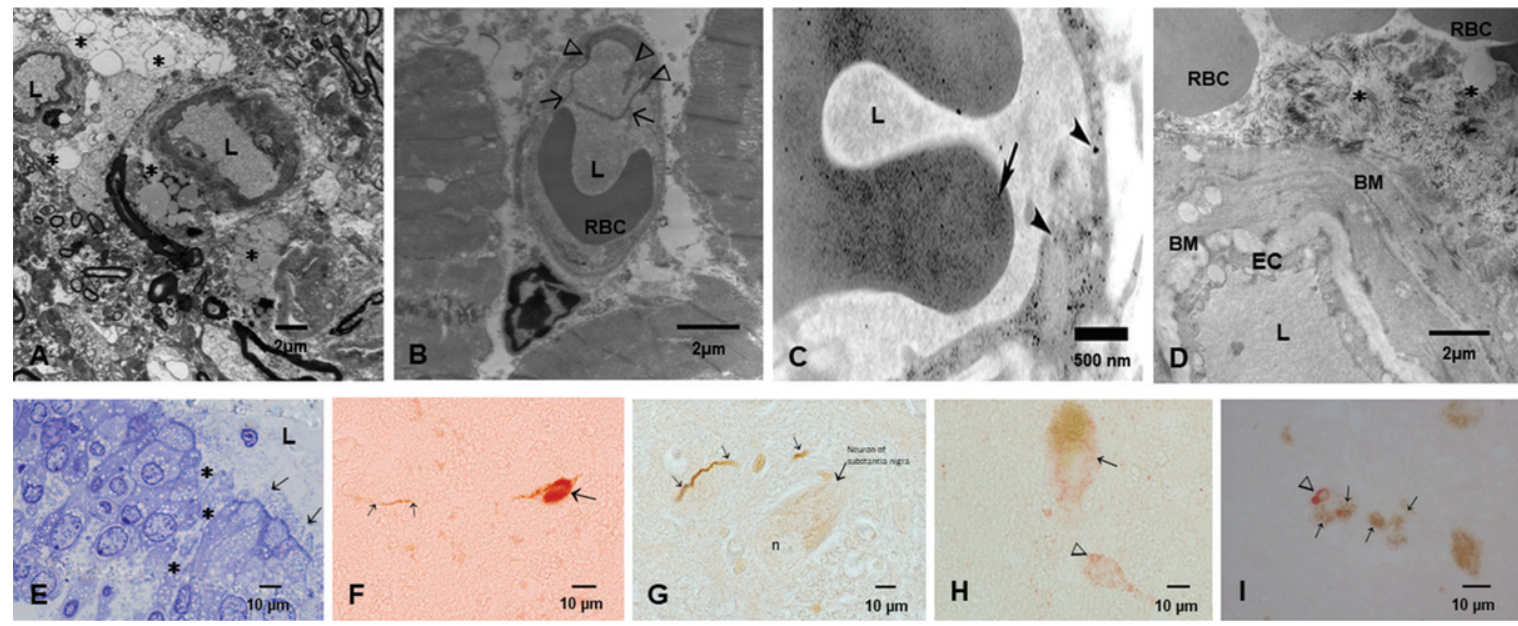

Fig. 4. The key early neural damage in Mexico City residents is the endothelium of the brain capillaries with an abnormal neurovascular unit. The damage is present in early childhood and it gets worse with age in the absence of any comorbidities. A) Brain neurovascular unit showing a central capillary with an extensive damage to the perivascular neuropil, including vacuolization $(*)$ and fragmentation of the neuropil with abnormal extravascular accumulation of lipids, the result of leaking vessels. B) A left ventricular blood vessel with marked endothelial activation as evidenced by multiple endothelial intraluminal extensions C) A capillary in the myocardium showing extensive caveolar activity and location of nanoparticles inside endothelial cells (arrowheads), while the red blood cell shows also nanoparticulates (long arrow) D) A chronically damaged olfactory bulb vessel with thick basement membranes (BM) A significant amount of fibrillary material is seen in perivascular location (*). Basically, Mexico City residents have no normal neural or heart blood vessels from childhood. E) One micron toluidine blue section of nasal respiratory epithelium, extensive areas of breakdown of the barriers are common findings (*), while ciliated epithelial cells show a decreased number of cilia (arrows). F) A lower cervical $\mathrm{p} \tau$ positive neuron in an 11-year-old female. G) Hyperphosphorylated tau neurites in the substantia nigra of a female teen. $\mathrm{H}$ ) Alpha-synuclein is positive in substantia nigra neurons in a young adolescent. I) An older subject shows Lewy bodies (arrowhead) in substantia nigra neurons. The early spectrum of both AD and PD pathology is seen from pediatric ages.

SARS-CoV-2. ACE2 is depleted in MMC residents, in keeping with the AD literature [202].

\section{CONCLUSIONS AND FUTURE DIRECTIONS}

The SARS-CoV-2 virus has caused a complex serious health global problem and in Mexico a preCOVID disastrous economic performance for 2020 with a contraction in gross domestic product worsen the situation. According with the National Council for the Evaluation of Social Development Policy (CONEVAL, [10]) the number of Mexicans in 2018 living in poverty was approximately 53.4 million with projections of 10 million more associated with the COVID crisis. Bello-Chavolla et al. [308] proposed a predictive score for SARS-CoV-2 lethality including age $\geq 65$ years, diabetes, early-onset diabetes, obesity, chronic kidney disease, hypertension, and immunosuppression significantly discriminated lethal from non-lethal cases $(\mathrm{C}$-statistic $=0.823)$. Strikingly, obesity mediated $49.5 \%$ of the effect of diabetes on COVID-19 lethality. Héctor Hiram Hernández Bringas [309], researcher at the Uni- versidad Nacional Autónoma de México (UNAM), has clear information about the vulnerable affected groups: $84 \%$ of SARS-CoV-2 deaths are poor and unemployed citizens, including housewives (28.1\%), street vendors, police, factory workers, brick layers $(16.8 \%)$, retired workers and pension workers (12\%), government workers (including health workers) (11.7\%), and public transportation workers $(8.5 \%)$. The fact $71.2 \%$ of affected Mexican citizens only had elementary education or they never attended school reflects their lack of access to preventive medicine, healthy diets, and steady jobs. Only $13.1 \%$ of deaths included citizens that attended college or had graduate school education. For MMC, the epicenter of the country's pandemic, the situation is grim; the highest number of COVID 19 cases and the highest mortality rate $(\sim 32 \%)$ are located in the Metropolitan area coinciding with the highest numbers of unemployed people, lower SES, violence, drug addition, food insecurity, lack of water, and no access to health coverage. Mexico ranks near the bottom in testing among Latin American countries: 99 tests per 100,000 residents as of May 15, 2020 [310]. 
This is our reality as health providers, in a city where development of AD starts in childhood and we can stage AD in $99.25 \%$ of 134 consecutive autopsies $\leq 30$ years and where $66 \%$ of $\leq 30$ years urbanites have cognitive impairment. SARS-CoV-2 infections represent a significant threat for our population.

These are our needs: 1) To accurately surveil the number of individuals with exposure to SARS-CoV2. Understanding the patterns of viral distribution among our population is key for interventions to control virus spread and dissemination coupled with implementation of protocols to detect neurological and psychiatric changes in exposed subjects.

2) Defining the role of exposures to air pollution, occupation, age, and gender, and the higher risk of SARS-CoV-2 should be prioritized. We know a priori air pollution is a risk factor for the development of both $\mathrm{AD}$ and $\mathrm{PD}$ in $\mathrm{MMC}$ residents, thus adding the risk of SARS-CoV-2 to the equation will translate in a potential acceleration of neuroinflammatory and neurodegenerative processes.

3) MMC children are historically a group characterized by significant systemic and neural inflammation, immunosuppression, cognitive impairment, and brain spectroscopic and magnetic resonance abnormalities [311-321]. Because of the mild or asymptomatic clinical SARS-CoV-2 infections in pediatric populations and their capacity to transmit the disease within the family, school, and play environments, we need to test our seemingly health pediatric populations and explore their response to the virus. Our major concern in pediatric cohorts is the development of neurological and/or psychiatric short and long-term complications resulting from the synergistic action of environmental air pollution and SARS-CoV-2. Acceleration of their neuroinflammation and progression of $\mathrm{AD}$ and $\mathrm{PD}$ pathology are particularly troublesome in children.

4) Forensic autopsies surveillance for SARS-CoV2 is a must. We need to know where the virus can be localized and do exhaustive brain sampling to look for viral pathology and AD/PD neuropathology including staging for both and sampling ocular conjunctiva, cerebrospinal fluid, supra and infratentorial brain anatomical regions, and the neuroenteric system.

There is no doubt that millions of Mexicans and millions of people across the world are exposed to complex mixtures of air pollutants and to the new SARS-CoV-2 virus and their responses to both will be an interplay of genetics, systemic and neural inflammatory responses, insulin resistance, hyperleptinemia, diabetes, APOE4, lifestyle, socioeconomic factors, stress, violence, etc., signaling the trajectory of young people toward an unknown scenario. Are we prepared for the short- and long-term health effects of two major problems air pollution and viral neurotropic viruses? Are we prepared to surveil behavioral, cognitive, and neurological manifestations in children, teens, and young adults exposed to SARS-CoV-2 and air pollution? Are we ready to identify vulnerable populations and protect them? We are witnessing in MMC an accelerated AD process with striking progressive timelines starting in the pediatric ages. It is imperative to understand we also have disease modulators at work and equally important several abnormal folding proteins are identified in young urbanites. Nanoparticles are key for the strong damage to critical neural, heart, gastrointestinal, and neuroenteric structures and damage to mitochondria, endoplasmic reticulum, mitochondriaassociated endoplasmic reticulum, chromatin, and nuclear and cytoplasmic membranes along the early and sustained oxidative stress complete the cellular havoc we are documenting in children and teens. The cognition deficits are literally devastating [321].

MMC is a megacity with specific, well-defined PM problems: heavy diesel trucks are a major pollution source and excluding them from regulation is a major error, severely affecting 25 million people. For physicians, infectologists, pediatricians, neurologists, toxicologists, and neuropathologists, our goal is to learn how SARS-CoV-2 manage to enter the brain at ease, and how NPs contribute to the process. Is the neural damage synergistic? Are we accelerating the neurodegenerative process? Are we on verge of significant increments in suicides related to the neuroinflammation and advanced AD stages? We also need early non-invasive tools to diagnose AD [318, 319,322 ] and how exposures to ubiquitous radiofrequency electromagnetic radiation, mostly microwave radiation generated for wireless communication and surveillance technologies $[323,324]$ is making havoc of our brain's organelles. The complexity of AD and PD is now accompanied by the neurotropic capabilities of an unexpected guest and clinical challenges of diagnosing them at early stages await all of us on Earth.

\section{DISCLOSURE STATEMENT}

Authors' disclosures available online (https:// www.j-alz.com/manuscript-disclosures/20-0891r1). 


\section{REFERENCES}

[1] Hernández-Fernández F, Valencia HS, Barbella-Aponte RA, Collado-Jiménez R, Ayo- Martín Ó, Barrena C, Molina-Nuevo JD, García-García J, Lozano-Setién E, Alcahut-Rodriguez C, Martínez-Martín Á, SánchezLópez A, Segura T (2020) Cerebrovascular disease in patients with COVID-19: Neuroimaging, histological and clinical description. Brain, doi: 10.1093/brain/awaa239

[2] Ellul MA, Benjamin L, Singh B, Lant S, Michael BD, Easton A, Kneen R, Defres S, Sejvar J, Solomon T (2020) Neurological associations of COVID-19. Lancet Neurol 19, 767-783

[3] Fitsiori A, Pugin D, Thieffry C, Lalive P, Vargas MI (2020) Unusual microbleeds in brain MRI of COVID-19 patients. J Neuroimaging, doi: 10.1111/jon.12755

[4] Payus AO, Liew Sat Lin C, Mohd Noh M, Jeffree MS, Ali RA (2020) SARS-CoV-2 infection of the nervous system: A review of the literature on neurological involvement in novel coronavirus disease-(COVID-19). Bosn J Basic Med Sci 20, 283-292.

[5] Silva MTT, Lima M, Araujo AQ (2020) SARS-CoV-2: Should we be concerned about the nervous system? Am J Trop Med Hyg 103, 993-998.

[6] Reger MA, Stanley IH, Joiner TE (2020) Suicide mortality and coronavirus disease 2019-a perfect storm? JAMA Psychiatry, doi: 10.1001/jamapsychiatry.2020.1060

[7] Boika AV (2020) A post-COVID-19 Parkinsonism in the future? Mov Disord 35, 1094.

[8] Choi KR, Heilemann MV, Fauer A, Mead M (2020) A second pandemic: Mental health spillover from the novel coronavirus (COVID-19). J Am Psychiatr Nurses Assoc 26, 340-343.

[9] World Bank Data, Poverty \& Equity Brief Mexico Latin America \& the Caribbean, https://databank.worldbank. org/data/download/poverty/33EF03BB-9722-4AE2-ABC 7-AA2972D68AFE/Global_POVEQ_MEX.pdf, Accessed July 10,2020

[10] CONEVAL, Pobreza en México. https://www.coneval. org.mx/Medicion/Paginas/PobrezaInicio.aspx

[11] Romero-Pimentel AL, Mendoza-Morales RC, Fresan A, Garcia-Dolores F, Gonzalez-Saenz EE, Morales-Marin ME, Nicolini H, Borges G (2018) Demographic and clinical characteristics of completed suicides in Mexico City 2014-2015. Front Psychiatry 9, 402.

[12] Borges G, Orozco R, Villatoro J, Medina-Mora ME, Fleiz C, Díaz-Salazar J (2019) Suicide ideation and behavior in Mexico: Encodat 2016. Salud Publica Mex 61, 6-15.

[13] Zhen-Duan J, DeJonckheere M, Raglin Bignall WJ, Galván J, Saavedra N, Berenzon Gorn S (2020) Interpersonal violence and psychological well-being: Perspectives of low-income patients, social workers, and medical doctors in Mexico City, Mexico. J Interpers Violence, doi: $10.1177 / 0886260520915543$

[14] Torres-Jardón R (2018) Políticas públicas y su efecto en la calidad del aire de la Zona Metropolitana de la Ciudad de México. In Transversalidad de la Política del Aire en M éxico, Sosa Núñez GS, ed. Instituto Mora. México, pp. 43-74.

[15] Yucatan Times (2020) Quarantine exacerbated emotional crises in Mexico. The Yucatan Times. https://www.theyucatantimes.com/2020/08/quarantineexacerbated-emotional-crises-in-mexico/

[16] Jayaweera M, Perera H, Gunawardana B, Manatunge J (2020) Transmission of COVID-19 virus by droplets and aerosols: A critical review on the unresolved dichotomy. Environ Res 188, 109819.

[17] USEPA, NAAQS Standars Table, Last updated December 20, 2016, Accessed January 31, 2020. https://www.epa.gov/criteria-air-pollutants/naaqs-table

[18] Gonet T, Maher BA (2019) Airborne, vehicle-derived febearing nanoparticles in the urban environment: A review. Environ Sci Technol 53, 9970-9991.

[19] Miller MR, Newby DE (2020) Air pollution and cardiovascular disease: Car sick. Cardiovasc Res 116, 279-294.

[20] Calderón-Garcidueñas L, Azzarelli B, Acuna H, Garcia R, Gambling TM, Osnaya N, Monroy S, Del Rosario Tizapantzi M, Carson JL, Villarreal-Calderon A, Rewcastle B (2002) Air pollution and brain damage. Toxicol Pathol 30, 373-389.

[21] Calderón-Garcidueñas L, Maronpot RR, Torres-Jardon R, Henriquez-Roldan C, Schoonhoven R, Acuna-Ayala H, Villarreal-Calderon A, Nakamura J, Fernando R, Reed W, Azzarelli B, Swenberg JA (2003) DNA damage in nasal and brain tissues of canines exposed to air pollutants is associated with evidence of chronic brain inflammation and neurodegeneration. Toxicol Pathol 31, 524-538.

[22] Calderón-Garcidueñas L, Reed W, Maronpot RR, Henriquez-Roldán C, Delgado-Chavez R, CalderónGarcidueñas A, Dragustinovis I, Franco-Lira M, AragónFlores M, Solt AC, Altenburg M, Torres-Jardón R, Swenberg JA (2004) Brain inflammation and Alzheimer'slike pathology in individuals exposed to severe air pollution. Toxicol Pathol 32, 650-658.

[23] Jung CR, Lin YT, Hwang BF (2015) Ozone, particulate matter, and newly diagnosed Alzheimer's disease: A population-based cohort study in Taiwan. J Alzheimers Dis 44, 573-584.

[24] Oudin A, Forsberg B, Adolfsson AN, Lind N, Modig L, Nordin M, Nordin S, Adolfsson R, Nilsson LG (2016) Traffic-related air pollution and dementia incidence in Northern Sweden: A longitudinal study. Environ Health Perspect 124, 306-312.

[25] Chen H, Kwong JC, Copes R, Tu K, Villeneuve PJ, van Donkelaar A, Hystad P, Martin RV, Murray BJ, Jessiman B, Wilton AS, Kopp A, Burnett RT (2017) Living near major roads and the incidence of dementia, Parkinson's disease, and multiple sclerosis: A population-based cohort study. Lancet 389, 718-726.

[26] Tsai TL, Lin YT, Hwang BF, Nakayama SF, Tsai CH, Sun XL, Ma C, Jung CR (2019) Fine particulate matter is a potential determinant of Alzheimer's disease: A systemic review and meta-analysis. Environ Res 177, 108638.

[27] Brito-Aguilar R (2019) Dementia around the world and the Latin America and Mexican scenarios. J Alzheimers Dis 71, 1-5.

[28] Carey IM, Anderson HR, Atkinson RW, Beevers SD, Cook DG, Strachan DP, Dajnak D, Gulliver J, Kelly FJ (2018) Are noise and air pollution related to the incidence of dementia? A cohort study in London, England. BMJ Open 8, e022404.

[29] Su JG, Apte JS, Lipsitt J, Garcia-Gonzalez DA, Beckerman BS, de Nazelle A, Texcalac-Sangrador JL, Jerrett M (2015) Populations potentially exposed to trafficrelated air pollution in seven world cities. Environ Int 78, 82-89.

[30] Tayarani M, Rowangould G (2020) Estimating exposure to fine particulate matter emissions from vehicle traffic: Exposure misclassification and daily activity patterns in a large, sprawling region. Environ Res 182, 108999. 
[31] Rowangould GM (2013) A census of the US near-roadway population: Public health and environmental justice considerations. Transp Res D Transp Environ 25, 59-67.

[32] Molina LT, Madronich S, Gaffney JS, Apel E, de Foy B, Fast J, Ferrare R, Herndon S, Jimenez JL, Lamb B, Osornio-Vargas AR, Russell P, Schauer JJ, Stevens PS, Volkamer R, Zavala M (2010) An overview of the MILAGRO 2006 campaign: Mexico City emissions and their transport and transformation. Atmos Chem Phys 10, 86978760 .

[33] Molina LT, Velasco E, Retama A, Zavala M (2019) Experience from integrated air quality management in the Mexico City metropolitan area and Singapore. Atmosphere 10, 512.

[34] González-Maciel A, Reynoso-Robles R, Torres-Jardón R, Mukherjee PS, Calderón-Garcidueñas L (2017) Combustion-derived nanoparticles in key brain target cells and organelles in young urbanites: Culprit hidden in plain sight in Alzheimer's disease development. J Alzheimers Dis 59, 189-208.

[35] Calderón-Garcidueñas L, Solt AC, Henríquez-Roldán C, Torres-Jardón R, Nuse B, Herritt L, Villarreal-Calderón R, Osnaya N, Stone I, García R, Brooks DM, GonzálezMaciel A, Reynoso-Robles R, Delgado-Chávez R, Reed W (2008) Long-term air pollution exposure is associated with neuroinflammation, an altered innate immune response, disruption of the blood-brain barrier, ultrafine particulate deposition, and accumulation of amyloid $\beta-42$ and $\alpha$-synuclein in children and young adults. Toxicol Pathol 36, 289-310.

[36] Calderón-Garcidueñas L, Franco-Lira M, Mora-Tiscareño A, Medina-Cortina H, Torres-Jardón R, Kavanaugh M (2013) Early Alzheimer's and Parkinson's disease pathology in urban children: Friend versus foe responses-it is time to face the evidence. Biomed Res Int 2013, 161687.

[37] Calderón-Garcidueñas L, Gónzalez-Maciel A, ReynosoRobles R, Delgado-Chávez R, Mukherjee PS, Kulesza RJ, Torres-Jardón R, Ávila-Ramírez J, Villarreal-Ríos R (2018a) Hallmarks of Alzheimer disease are evolving relentlessly in Metropolitan Mexico City infants, children and young adults. APOE4 carriers have higher suicide risk and higher odds of reaching NFT stage $V$ at $\leq 40$ years of age. Environ Res 164, 475-487.

[38] Calderón-Garcidueñas L, González-Maciel A, ReynosoRobles R, Kulesza RJ, Mukherjee PS, Torres-Jardón R, Rönkkö T, Doty RL (2018) Alzheimer's disease and alphasynuclein pathology in the olfactory bulbs of infants, children, teens and adults $\leq 40$ years in Metropolitan Mexico City. APOE4 carriers at higher risk of suicide accelerate their olfactory bulb pathology. Environ Res 166, 348-362.

[39] Calderón-Garcidueñas L, González-Maciel A, Mukherjee PS, Reynoso-Robles R, Pérez-Guillé B, Gayosso-Chávez C, Torres-Jardón R, Cross JV, Ahmed IAM, Karloukovski VV, Maher BA (2019) Combustion- and friction-derived magnetic air pollution nanoparticles in human hearts. Environ Res 176, 108567.

[40] Maher BA, Ahmed IAM, Karloukovski V, MacLaren DA, Foulds PG, Allsop D, Mann DMA, Torres-Jardón R, Calderon-Garciduenas L (2016) Magnetite pollution nanoparticles in the human brain. Proc Natl Acad Sci U S A 113, 10797-10801.

[41] Maher BA, González-Maciel A, Reynoso-Robles R, Torres-Jardón R, Calderón-Garcidueñas L (2020) Ironrich air pollution nanoparticles: An unrecognised environmental risk factor for myocardial mitochondrial dysfunction and cardiac oxidative stress. Environ Res 188, 109816.

[42] Lu D, Luo Q, Chen R, Zhuansun Y, Jiang J, Wang W, Yang X, Zhang L, Liu X, Li F, Liu Q, Jiang G (2020) Chemical multi-fingerprinting of exogenous ultrafine particles in human serum and pleural effusion. Nat Commun 11, 2567.

[43] Zhang R, Li Y, Zhang AL, Wang Y, Molina MJ (2020) Identifying airborne transmission as the dominant route for the spread of COVID-19. Proc Natl Acad Sci U S A 117, 14857-14863.

[44] Setti L, Passarini F, De Gennaro G, Barbieri P, Pallavicini A, Ruscio M, Piscitelli P, Colao A, Miani A (2020) Searching for SARS-COV-2 on particulate matter: A possible early indicator of COVID-19 epidemic recurrence. Int $J$ Environ Res Public Health 17, 2986.

[45] NASA (2019) Wildfire Smoke Shrouds Mexico City. https://earthobservatory.nasa.gov/images/145062/wildfire -smoke-shrouds-mexico-city, Last updated May 16, 2019, Accessed on May 16, 2019.

[46] Cortés-Hernández VE, Aparicio J (2014) Caracterización de aerosoles por quema de biomasa en el sureste de México. Tecnol Ciencias Agua 5, 145-156.

[47] Edgerton SA, Bian X, Doran JC, Fast JD, Hubbe JM, Malone EL, Shaw WJ, Whiteman CD, Zhong S, Arriaga JL, Ortiz E, Ruiz M, Sosa G, Vega E, Limon T, Guzman F, Archuleta J, Bossert JE, Elliot SM, Lee JT, McNair LA, Chow JC, Watson JG, Coulter RL, Doskey PV, Gaffney JS, Marley NA, Neff W, Petty R (1999) Particulate air pollution in Mexico City: A collaborative research project. $J$ Air Waste Manag Assoc 49, 1221-1229.

[48] Jiang M, Marr LC, Dunlea EJ, Herndon SC, Jayne JT, Kolb CE, Knighton WB, Rogers TM, Zavala M, Molina LT, Molina MJ (2005) Vehicle fleet emissions of black carbon, polycyclic aromatic hydrocarbons, and other pollutants measured by a mobile laboratory in Mexico City. Atmos Chem Phys 5, 3377-3387.

[49] Baumgardner D, Kok GL, Raga GB (2007) On the diurnal variability of particle properties related to light absorbing carbon in Mexico City. Atmos Chem Phys 7, 2517-2526.

[50] Villalobos-Pietrini R, Amador-Munoz O, ValleHernandez BL, Gomez-Arroyo S, Waliszewski S, Jazcilevich A (2011) Organic compound in airborne particles and their genottoxic effects in Mexico City. In Air Quality Monitoring, Assessment and Management, Mazzeo NA, ed. IntechOpen, pp. 345-378.

[51] Retama A, Baumgardner D, Raga GB, McMeeking GR, Walker JW (2015) Seasonal and diurnal trends in black carbon properties and co-pollutants in Mexico City. Atmos Chem Phys 15, 9693-9709.

[52] Guerrero F, Alvarez-Ospina H, Retama A, Lopez-Medina A, Castro T, Salcedo D (2017) Seasonal changes in the PM 1 chemical composition north of Mexico City. Atmósfera 30, 1-9.

[53] Ladino LA, Raga GB, Baumgardner D (2018) On particlebound polycyclic aromatic hydrocarbons (PPAH) and links to gaseous emissions in Mexico City. Atmos Environ 194, 31-40.

[54] Peralta O, Ortínez-Alvarez A, Basaldud R, Santiago $\mathrm{N}$, Alvarez-Ospina $\mathrm{H}$, de la Cruz K, Barrera V, de la Luz Espinosa M, Saavedra I, Castro T, Martínez-Arroyo A, Páramo VH, Ruíz-Suárez LG, Vazquez-Galvez FA, Gavilán A (2019) Atmospheric black carbon concentrations in Mexico. Atmos Res 230, 104626. 
[55] Sanità di Toppi L, Sanità di Toppi L, Bellini E (2020) Novel coronavirus: How atmospheric particulate affects our environment and health. Challenges 11, 6 .

[56] Velasco E, Retama A (2017) Ozone's threat hits back Mexico City. Sustain Cities Soc 31, 260-263.

[57] Rodríguez S, Huerta G, Reyes H, Rodríguez S, Huerta G, Reyes H (2016) A study of trends for Mexico City ozone extremes: 2001-2014. Atmósfera 29, 107-120.

[58] SEDEMA 2020. Secretaría del Medio Ambiente de la Ciudad de México. Inventario de Emisiones de la Ciudad de México 2016. Dirección General de Gestión de la Calidad del Aire, Dirección de Programas de Calidad del Aire e Inventario de Emisiones. Ciudad de México. http://www.aire.cdmx.gob.mx/descargas/publicaciones/ flippingbook/inventario-emisiones-2016/mobile/ inventario-emisiones-2016.pdf

[59] Peralta Ramos JM, Iribarren P, Bousset L, Melki R, Baekelandt V, Van der Perren A (2019) Peripheral inflammation regulates CNS immune surveillance through the recruitment of inflammatory monocytes upon systemic $\alpha$-synuclein administration. Front Immunol 10, 80 .

[60] Li N, Georas S, Alexis N, Fritz P, Xia T, Williams MA, Horner E, Nel A (2016) A work group report on ultrafine particles (American Academy of Allergy, Asthma \& Immunology): Why ambient ultrafine and engineered nanoparticles should receive special attention for possible adverse health outcomes in human subjects. J Allergy Clin Immunol 138, 386-396.

[61] Teleanu DM, Chircov C, Grumezescu AM, Volceanov A, Teleanu RI (2018) Impact of nanoparticles on brain health: An up to date overview. J Clin Med 7, 490.

[62] Barbero F, Russo L, Vitali M, Piella J, Salvo I, Borrajo ML, Busquets-Fité M, Grandori R, Bastús NG, Casals E, Puntes V (2017) Formation of the protein corona: The interface between nanoparticles and the immune system. Semin Immunol 34, 52-60.

[63] Faisal N, Kumar K (2017) Polymer and metal nanocomposites in biomedical applications. Biointerface Res Appl Chem 7, 2286-2294.

[64] Wu T, Tang M (2018) Review of the effects of manufactured nanoparticles on mammalian target organs. J Appl Toxicol 38, 25-40.

[65] Ivanov AO, Camp PJ (2018) Theory of the dynamic magnetic susceptibility of ferrofluids. Phys Rev E 98, 050602.

[66] Maher BA (2019) Airborne magnetite- and iron-rich pollution nanoparticles: Potential neurotoxicants and environmental risk factors for neurodegenerative disease, including Alzheimer's disease. J Alzheimers Dis 71, 361375.

[67] Calderón-Garcidueñas L, Reynoso-Robles R, GonzálezMaciel A (2019) Combustion and friction-derived nanoparticles and industrial-sourced nanoparticles: The culprit of Alzheimer and Parkinson's diseases. Environ Res 176, 108574.

[68] Dąbrowska-Bouta B, Sulkowski G, Strużyński W, Strużyńska L (2019) Prolonged exposure to silver nanoparticles results in oxidative stress in cerebral myelin. Neurotox Res 35, 495-504.

[69] Zhou Y, Peng Z, Seven ES, Leblanc RM (2018) Crossing the blood-brain barrier with nanoparticles. $J$ Control Release 270, 290-303.

[70] Koyuncu OO, Hogue IB, Enquist LW (2013) Virus infections in the nervous system. Cell Host Microbe 13, 379-393.
[71] Desforges M, Le Coupanec A, Dubeau P, Bourgouin A, Lajoie L, Dubé M, Talbot PJ (2020) Human coronaviruses and other respiratory viruses: Underestimated opportunistic pathogens of the central nervous system? Viruses 12, 14.

[72] Wu Y, Xu X, Chen Z, Duan J, Hashimoto K, Yang L, Liu C, Yang C (2020) Nervous system involvement after infection with COVID-19 and other coronaviruses. Brain Behav Immun 87, 18-22.

[73] Brenner JS, Pan DC, Myerson JW, Marcos-Contreras OA, Villa CH, Patel P, Hekierski H, Chatterjee S, Tao JQ, Parhiz H, Bhamidipati K, Uhler TG, Hood ED, Kiseleva RY, Shuvaev VS, Shuvaeva T, Khoshnejad M, Johnston I, Gregory JV, Lahann J, Wang T, Cantu E, Armstead WM, Mitragotri S, Muzykantov V (2018) Red blood cell-hitchhiking boosts delivery of nanocarriers to chosen organs by orders of magnitude. Nat Commun 9, 2684.

[74] Desforges M, Coupanec AL, Brison é, Meessen-Pinard M, Talbot PJ (2014) Human respiratory coronaviruses: Neuroinvasive, neurotropic and potentially neurovirulent pathogens. Virologie (Montrouge) 18, 5-16.

[75] Li K, Hao Z, Zhao X, Du J, Zhou Y (2020) SARS-CoV2 infection-induced immune responses: Friends or foes? Scand J Immunol 92, e12895.

[76] Calderón-Garcidueñas L, Franco-Lira M, HenríquezRoldán C, Osnaya N, González-Maciel A, ReynosoRobles R, Villarreal-Calderon R, Herritt L, Brooks D, Keefe S, Palacios-Moreno J, Villarreal-Calderon R, Torres-Jardón R, Medina-Cortina H, Delgado-Chávez R, Aiello-Mora M, Maronpot RR, Doty RL (2010) Urban air pollution: Influences on olfactory function and pathology in exposed children and young adults. Exp Toxicol Pathol 62, 91-102.

[77] Doty RL, Hawkes CH (2019) Chemosensory dysfunction in neurodegenerative diseases. In Handbook of Clinical Neurology, Doty RL, ed. Elsevier, pp. 325-360.

[78] Roos DS, Twisk JWR, Raijmakers PGHM, Doty RL, Berendse HW (2019) Hyposmia as a marker of (non)motor disease severity in Parkinson's disease. J Neural Transm (Vienna) 126, 1471-1478.

[79] Hwang CS (2006) Olfactory neuropathy in severe acute respiratory syndrome: Report of A case. Acta Neurol Taiwan 15, 26-28.

[80] Mao L, Wang M, Chen S, He Q, Chang J, Hong C, Zhou Y, Wang D, Li Y, Jin H, Hu B (2020) Neurological manifestations of hospitalized patients with COVID-19 in Wuhan, China: A retrospective case series study. JAMA Neurol 77, $1-9$.

[81] Heidari F, Karimi E, Firouzifar M, Khamushian P, Ansari R, Mohammadi Ardehali M, Heidari F (2020) Anosmia as a prominent symptom of COVID-19 infection. Rhinology 58, 302-303.

[82] Russell B, Moss C, Rigg A, Hopkins C, Papa S, Van Hemelrijck M (2020) Anosmia and ageusia are emerging as symptoms in patients with COVID-19: What does the current evidence say? Ecancermedicalscience 14, ed98.

[83] Vaira LA, Salzano G, Deiana G, De Riu G (2020) Anosmia and Ageusia: Common findings in COVID-19 patients. Laryngoscope 130, 1787.

[84] Karimi-Galougahi M, Raad N, Mikaniki N (2020) Anosmia and the need for COVID-19 screening during the pandemic. Otolaryngol Head Neck Surg 163, 96-97.

[85] Ceran BB, Ozates S (2020) Ocular manifestations of coronavirus disease 2019. Graefes Arch Clin Exp Ophthalmol 258, 1959-1963. 
[86] Valente P, Iarossi G, Federici M, Petroni S, Palma P, Cotugno N, De Ioris MA, Campana A, Buzzonetti L (2020) Ocular manifestations and viral shedding in tears of pediatric patients with coronavirus disease 2019: A preliminary report. $J$ AAPOS, doi: 10.1016/j.jaapos.2020.05.002

[87] Karimi S, Arabi A, Shahraki T, Safi S (2020) Detection of severe acute respiratory syndrome coronavirus- 2 in the tears of patients with coronavirus disease 2019. Eye (Lond) 34, 1220-1223.

[88] Liu Q, Shen Y, Chen J, Gao X, Feng C, Wang L, Zhang Q, Jiang X (2012) Nose-to-brain transport pathways of wheat germ agglutinin conjugated PEG-PLA nanoparticles. Pharm Res 29, 546-558.

[89] Malhotra M, Tomaro-Duchesneau C, Saha S, Prakash S (2014) Intranasal delivery of chitosan-siRNA nanoparticle formulation to the brain. In Drug Delivery System, Jain KK, ed. Springer, New York, NY, pp. 233-247.

[90] Selvaraj K, Gowthamarajan K, Karri VVSR (2018) Nose to brain transport pathways an overview: Potential of nanostructured lipid carriers in nose to brain targeting. Artif Cells Nanomed Biotechnol 46, 2088-2095.

[91] Li J, Tang M, Xue Y (2019) Review of the effects of silver nanoparticle exposure on gut bacteria. J Appl Toxicol 39, 27-37.

[92] Lundquist P, Artursson P (2016) Oral absorption of peptides and nanoparticles across the human intestine: Opportunities, limitations and studies in human tissues. Adv Drug Deliv Rev 106, 256-276.

[93] D'Amico F, Baumgart DC, Danese S, Peyrin-Biroulet L (2020) Diarrhea during COVID-19 infection: Pathogenesis, epidemiology, prevention, and management. Clin Gastroenterol Hepatol 18, 1663-1672.

[94] Wong SH, Lui RN, Sung JJ (2020) COVID-19 and the digestive system. J Gastroenterol Hepatol 35, 744-748.

[95] Calderón-Garcidueñas L, Vojdani A, Blaurock-Busch E, Busch Y, Friedle A, Franco-Lira M, Sarathi-Mukherjee P, Martínez-Aguirre X, Park SB, Torres-Jardón R, D'Angiulli A (2015) Air pollution and children: Neural and tight junction antibodies and combustion metals, the role of barrier breakdown and brain immunity in neurodegeneration. J Alzheimers Dis 43, 1039-1058.

[96] Calderón-Garcidueñas L, Reynoso-Robles R, PérezGuillé B, Mukherjee PS, Gónzalez-Maciel A (2017) Combustion-derived nanoparticles, the neuroenteric system, cervical vagus, hyperphosphorylated alpha synuclein and tau in young Mexico City residents. Environ Res 159, 186-201.

[97] Iadecola C (2017) The neurovascular unit coming of age: A journey through neurovascular coupling in health and disease. Neuron 96, 17-42.

[98] Calderón-Garcidueñas L, Reynoso-Robles R, VargasMartínez J, Gómez-Maqueo-Chew A, Pérez-Guillé B, Mukherjee PS, Torres-Jardón R, Perry G, GónzalezMaciel A (2016) Prefrontal white matter pathology in air pollution exposed Mexico City young urbanites and their potential impact on neurovascular unit dysfunction and the development of Alzheimer's disease. Environ Res 146, 404-417.

[99] Sekar D, Johnson J, Biruntha M, Lakhmanan G, Gurunathan D, Ross-Houle K (2019) Biological and clinical relevance of microRNAs in mitochondrial diseases. DNA Cell Biol 39, 1379-1384.

[100] Chakravorty A, Jetto CT, Manjithaya R (2019) Dysfunctional mitochondria and mitophagy as drivers of
Alzheimer's disease pathogenesis. Front Aging Neurosci 11, 311 .

[101] Eramo MJ, Lisnyak V, Formosa LE, Ryan MT (2020) The 'mitochondrial contact site and cristae organising system' (MICOS) in health and human disease. J Biochem 167, 243-255.

[102] Dasgupta S (2019) Mitochondrion: I am more than a fuel server. Ann Transl Med 7, 594.

[103] Deus CM, Yambire KF, Oliveira PJ, Raimundo N (2020) Mitochondria-lysosome crosstalk: From physiology to neurodegeneration. Trends Mol Med 26, 71-88.

[104] Ji T, Zhang X, Xin Z, Xu B, Jin Z, Wu J, Hu W, Yang $Y(2020)$ Does perturbation in the mitochondrial protein folding pave the way for neurodegeneration diseases? Ageing Res Rev 57, 100997.

[105] Barkhade T, Mishra S, Chander H, Mahapatra SK, Banerjee I (2019) Effect of $\mathrm{TiO} 2$ and $\mathrm{Fe}$ doped $\mathrm{TiO} 2$ nanoparticles on mitochondrial membrane potential in HBL-100 cells. Biointerphases 14, 041003.

[106] Kramer P, Bressan P (2018) Our (mother's) mitochondria and our mind. Perspect Psychol Sci 13, 88-100.

[107] Rana SVS (2020) Endoplasmic reticulum stress induced by toxic elements - a review of recent developments. Biol Trace Elem Res 196, 10-19.

[108] Sipos A, Kim KJ, Sioutas C, Crandall ED (2019) Evidence for nanoparticle-induced lysosomal dysfunction in lung adenocarcinoma (A549) Cells. Int J Mol Sci 20, 5253.

[109] Sokolova V, Nzou G, van der Meer SB, Ruks T, Heggen M, Loza K, Hagemann N, Murke F, Giebel B, Hermann DM, Atala AJ, Epple M (2020) Ultrasmall gold nanoparticles $(2 \mathrm{~nm})$ can penetrate and enter cell nuclei in an in vitro $3 \mathrm{D}$ brain spheroid model. Acta Biomater 111, 349-362.

[110] Cedervall T, Lynch I, Lindman S, Berggård T, Thulin E, Nilsson H, Dawson KA, Linse S (2007) Understanding the nanoparticle-protein corona using methods to quantify exchange rates and affinities of proteins for nanoparticles. Proc Natl Acad Sci U S A 104, 2050-2055.

[111] Lynch I, Cedervall T, Lundqvist M, Cabaleiro-Lago C, Linse S, Dawson KA (2007) The nanoparticle-protein complex as a biological entity; a complex fluids and surface science challenge for the 21st century. Adv Colloid Interface Sci 134-135, 167-174.

[112] Ali N, Mattsson K, Rissler J, Karlsson HM, Svensson CR, Gudmundsson A, Lindh CH, Jönsson BAG, Cedervall T, Kåredal M (2016) Analysis of nanoparticle-protein coronas formed in vitro between nanosized welding particles and nasal lavage proteins. Nanotoxicology 10, 226-234.

[113] Lundqvist M, Augustsson C, Lilja M, Lundkvist K, Dahlbäck B, Linse S, Cedervall T (2017) The nanoparticle protein corona formed in human blood or human blood fractions. PLoS One 12, e0175871.

[114] Ahsan SM, Rao CM, Ahmad MdF (2018) Nanoparticleprotein interaction: The significance and role of protein corona. In Cellular and Molecular Toxicology of Nanoparticles, Saquib Q, Faisal M, Al-Khedhairy AA, Alatar AA, eds. Springer International Publishing, Cham, pp. 175198.

[115] Ezzat K, Pernemalm M, Pålsson S, Roberts TC, Järver P, Dondalska A, Bestas B, Sobkowiak MJ, Levänen B, Sköld M, Thompson EA, Saher O, Kari OK, Lajunen T, Sverremark Ekström E, Nilsson C, Ishchenko Y, Malm T, Wood MJA, Power UF, Masich S, Lindén A, Sandberg JK, Lehtiö J, Spetz AL, EL Andaloussi S (2019) The viral protein corona directs viral pathogenesis and amyloid aggregation. Nat Commun 10, 2331. 
[116] Limphaibool N, Iwanowski P, Holstad MJV, Kobylarek D, Kozubski W (2019) Infectious etiologies of parkinsonism: Pathomechanisms and clinical implications. Front Neurol 10, 652 .

[117] Lipsitch M, Swerdlow DL, Finelli L (2020) Defining the epidemiology of COVID-19 - studies needed. $N$ Engl $J$ Med 382, 1194-1196.

[118] Berardi A, Bombelli FB, Thuenemann EC, Lomonossoff GP (2019) Viral nanoparticles can elude protein barriers: Exploiting rather than imitating nature. Nanoscale 11, 2306-2316.

[119] Abbott N (2013) Blood-brain barrier structure and function and the challenges for CNS drug delivery. $J$ Inherit Metab Dis 36, 437-449.

[120] Marchetti M (2020) COVID-19-driven endothelial damage: Complement, HIF-1, and ABL2 are potential pathways of damage and targets for cure. Ann Hematol 99, 1701-1707.

[121] Iba T, Levy JH, Levi M, Thachil J (2020) Coagulopathy in COVID-19. J Thromb Haemost, doi: 10.1111/jth.14975

[122] Inal J (2020) COVID-19 comorbidities, associated pro-coagulant extracellular vesicles and venous thromboembolisms: A possible link with ethnicity? $\mathrm{Br} J$ Haematol, doi: 10.1111/bjh.17011

[123] Panfoli I (2020) Potential role of endothelial cell surface ectopic redox complexes in COVID-19 disease pathogenesis. Clin Med, doi: 10.7861/clinmed.2020-0252

[124] Colmenero I, Santonja C, Alonso-Riaño M, NogueraMorel L, Hernández-Martín A, Andina D, Wiesner T, Rodríguez-Peralto JL, Requena L, Torrelo (2020) A SARS-CoV-2 endothelial infection causes COVID-19 chilblains: Histopathological, immunohistochemical and ultraestructural study of 7 paediatric cases. Br J Dermatol, doi: 10.1111/bjd.19327

[125] Bavishi C, Bonow RO, Trivedi V, Abbott JD, Messerli FH, Bhatt DL (2020) Acute myocardial injury in patients hospitalized with COVID-19 infection: A review. Prog Cardiovasc Dis, doi: 10.1016/j.pcad.2020.05.013

[126] Carnevale S, Beretta P, Morbini P (2020) Direct endothelial damage and vasculitis due to SARS-CoV-2 in small bowel submucosa of COVID-19 patient with diarrhea. $J$ Med Virol, doi: 10.1002/jmv.26119

[127] Disdier C, Chalansonnet M, Gagnaire F, Gaté L, Cosnier F, Devoy J, Saba W, Lund AK, Brun E, Mabondzo A (2017) Brain inflammation, blood brain barrier dysfunction and neuronal synaptophysin decrease after inhalation exposure to titanium dioxide nano-aerosol in aging rats. Sci Rep 7, 12196.

[128] Ehsanifar M, Tameh AA, Farzadkia M, Kalantari RR, Zavareh MS, Nikzaad H, Jafari AJ (2019) Exposure to nanoscale diesel exhaust particles: Oxidative stress, neuroinflammation, anxiety and depression on adult male mice. Ecotoxicol Environ Saf 168, 338-347.

[129] Aijie C, Huimin L, Jia L, Lingling O, Limin W, Junrong W, Xuan L, Xue H, Longquan S (2017) Central neurotoxicity induced by the instillation of $\mathrm{ZnO}$ and $\mathrm{TiO} 2$ nanoparticles through the taste nerve pathway. Nanomedicine (Lond) 12, 2453-2470.

[130] Vakili-Ghartavol R, Momtazi-Borojeni AA, VakiliGhartavol Z, Aiyelabegan HT, Jaafari MR, Rezayat SM, Bidgoli SA (2020) Toxicity assessment of superparamagnetic iron oxide nanoparticles in different tissues. Artif Cells Nanomed Biotechnol 48, 443-451.

[131] Mou X, Pilozzi A, Tailor B, Yi J, Cahill C, Rogers J, Huang X (2020) Exposure to $\mathrm{CuO}$ nanoparticles mediates
$\mathrm{NF} \kappa \mathrm{B}$ activation and enhances amyloid precursor protein expression. Biomedicines $\mathbf{8}, 45$.

[132] Liang H, Chen A, Lai X, Liu J, Wu J, Kang Y, Wang X, Shao L (2018) Neuroinflammation is induced by tongueinstilled $\mathrm{ZnO}$ nanoparticles via the $\mathrm{Ca} 2+$-dependent $\mathrm{NF}$ $\kappa \mathrm{B}$ and MAPK pathways. Part Fibre Toxicol 15, 39.

[133] Millward JM, Schnorr J, Taupitz M, Wagner S, Wuerfel JT, Infante-Duarte C (2013) Iron oxide magnetic nanoparticles highlight early involvement of the choroid plexus in central nervous system inflammation. ASN Neuro 5, e00110.

[134] McConnell HL, Schwartz DL, Richardson BE, Woltjer RL, Muldoon LL, Neuwelt EA (2016) Ferumoxytol nanoparticle uptake in brain during acute neuroinflammation is cell-specific. Nanomedicine 12, 1535-1542.

[135] Berndt D, Millward JM, Schnorr J, Taupitz M, Stangl V, Paul F, Wagner S, Wuerfel JT, Sack I, Ludwig A, InfanteDuarte C (2017) Inflammation-induced brain endothelial activation leads to uptake of electrostatically stabilized iron oxide nanoparticles via sulfated glycosaminoglycans. Nanomedicine 13, 1411-1421.

[136] Chen CM, Wu ML, Ho YC, Gung PY, Tsai MH, Orekhov AN, Sobenin IA, Lin P, Yet SF (2020) Exposure to zinc oxide nanoparticles disrupts endothelial tight and adherens junctions and induces pulmonary inflammatory cell infiltration. Int J Mol Sci 21, 3437.

[137] Calderón-Garcidueñas L, Macías-Parra M, Hoffmann HJ, Valencia-Salazar G, Henríquez-Roldán C, Osnaya N, Monte OC, Barragán-Mejía G, Villarreal-Calderon R, Romero L, Granada-Macías M, Torres-Jardón R, MedinaCortina H, Maronpot RR (2009) Immunotoxicity and environment: Immunodysregulation and systemic inflammation in children. Toxicol Pathol 37, 161-169.

[138] Calderón-Garcidueñas L, Kavanaugh M, Block M, D’Angiulli A, Delgado-Chávez R, Torres-Jardón R, González-Maciel A, Reynoso-Robles R, Osnaya N, Villarreal-Calderon R, Guo R, Hua Z, Zhu H, Perry G, Diaz P (2012) Neuroinflammation, hyperphosphorylated tau, diffuse amyloid plaques, and down-regulation of the cellular prion protein in air pollution exposed children and young adults. $J$ Alzheimers Dis 28, 93-107.

[139] Ising C, Venegas C, Zhang S, Scheiblich H, Schmidt SV, Vieira-Saecker A, Schwartz S, Albasset S, McManus RM, Tejera D, Griep A, Santarelli F, Brosseron F, Opitz S, Stunden J, Merten M, Kayed R, Golenbock DT, Blum D, Latz E, Buée L, Heneka MT (2019) NLRP3 inflammasome activation drives tau pathology. Nature 575, 669-673.

[140] Park J, Baik SH, Mook-Jung I, Irimia D, Cho H (2019) Mimicry of central-peripheral immunity in Alzheimer's disease and discovery of neurodegenerative roles in neutrophil. Front Immunol 10, 2231.

[141] Jha NK, Jha SK, Kar R, Nand P, Swati K, Goswami VK (2019) Nuclear factor-kappa $\beta$ as a therapeutic target for Alzheimer's disease. J Neurochem 150, 113-137.

[142] Regen F, Hellmann-Regen J, Costantini E, Reale M (2017) Neuroinflammation and Alzheimer's disease: Implications for microglial activation. Curr Alzheimer Res 14, 1140-1148.

[143] Wilkins HM, Swerdlow RH (2016) Relationships between mitochondria and neuroinflammation: Implications for Alzheimer's disease. Curr Top Med Chem 16, 849-857.

[144] Zádori D, Veres G, Szalárdy L, Klivényi P, Vécsei L (2018) Alzheimer's disease: Recent concepts on the relation of mitochondrial disturbances, excitotoxicity, neuroinflammation, and kynurenines. J Alzheimers Dis 62, 523-547. 
[145] Presta I, Vismara MFM, Novellino F, Donato A, Zaffino P, Scali E, Pirrone KC, Spadea MF, Malara N, Donato G (2018) Innate immunity cells and the neurovascular unit. Int J Mol Sci 19, 3856.

[146] Streit WJ, Braak H, Tredici KD, Leyh J, Lier J, Khoshbouei H, Eisenlöffel C, Müller W, Bechmann I (2018) Microglial activation occurs late during preclinical Alzheimer's disease. Glia 66, 2550-2562.

[147] Zabel M, Nackenoff A, Kirsch WM, Harrison FE, Perry G, Schrag M (2018) Markers of oxidative damage to lipids, nucleic acids and proteins and antioxidant enzymes activities in Alzheimer's disease brain: A meta-analysis in human pathological specimens. Free Radic Biol Med 115, 351-360.

[148] Kant S, Stopa EG, Johanson CE, Baird A, Silverberg GD (2018) Choroid plexus genes for CSF production and brain homeostasis are altered in Alzheimer's disease. Fluids Barriers CNS 15, 34.

[149] Newcombe EA, Camats-Perna J, Silva ML, Valmas N, Huat TJ, Medeiros R (2018) Inflammation: The link between comorbidities, genetics, and Alzheimer's disease. J Neuroinflammation 15, 276.

[150] Stock AJ, Kasus-Jacobi A, Pereira HA (2018) The role of neutrophil granule proteins in neuroinflammation and Alzheimer's disease. J Neuroinflammation 15, 240.

[151] Janelidze S, Mattsson N, Stomrud E, Lindberg O, Palmqvist S, Zetterberg H, Blennow K, Hansson O (2018) CSF biomarkers of neuroinflammation and cerebrovascular dysfunction in early Alzheimer disease. Neurology $\mathbf{9 1}$, e867-e877.

[152] Boon BDC, Hoozemans JJM, Lopuhaä B, Eigenhuis KN, Scheltens P, Kamphorst W, Rozemuller AJM, Bouwman FH (2018) Neuroinflammation is increased in the parietal cortex of atypical Alzheimer's disease. J Neuroinflammation 15, 170.

[153] Yuan J, Amin P, Ofengeim D (2019) Necroptosis and RIPK1-mediated neuroinflammation in CNS diseases. Nat Rev Neurosci 20, 19-33.

[154] Barroeta-Espar I, Weinstock LD, Perez-Nievas BG, Meltzer AC, Siao Tick Chong M, Amaral AC, Murray ME, Moulder KL, Morris JC, Cairns NJ, Parisi JE, Lowe VJ, Petersen RC, Kofler J, Ikonomovic MD, López O, Klunk WE, Mayeux RP, Frosch MP, Wood LB, GomezIsla T (2019) Distinct cytokine profiles in human brains resilient to Alzheimer's pathology. Neurobiol Dis 121, 327-337.

[155] Stancu IC, Cremers N, Vanrusselt H, Couturier J, Vanoosthuyse A, Kessels S, Lodder C, Brône B, Huaux F, Octave JN, Terwel D, Dewachter I (2019) Aggregated Tau activates NLRP3-ASC inflammasome exacerbating exogenously seeded and non-exogenously seeded Tau pathology in vivo. Acta Neuropathol 137, 599-617.

[156] Saldi TK, Gonzales PK, LaRocca TJ, Link CD (2019) Neurodegeneration, heterochromatin, and doublestranded RNA. J Exp Neurosci 13, 1179069519830697.

[157] Taipa R, das Neves SP, Sousa AL, Fernandes J, Pinto C, Correia AP, Santos E, Pinto PS, Carneiro P, Costa P, Santos D, Alonso I, Palha J, Marques F, Cavaco S, Sousa N (2019) Proinflammatory and anti-inflammatory cytokines in the CSF of patients with Alzheimer's disease and their correlation with cognitive decline. Neurobiol Aging 76, 125-132.

[158] Ozansoy M, Başak AN (2013) The central theme of Parkinson's disease: $\alpha$-Synuclein. Mol Neurobiol 47, 460465 .
[159] Tysnes O-B, Storstein A (2017) Epidemiology of Parkinson's disease. J Neural Transm 124, 901-905.

[160] Lee HY, Lee M, Bae YS (2017) Formyl peptide receptors in cellular differentiation and inflammatory diseases. J Cell Biochem 118, 1300-1307.

[161] Nasrolahi A, Safari F, Farhoudi M, Khosravi A, Farajdokht F, Bastaminejad S, Shotorbani SS, Mahmoudi J (2019) Immune system and new avenues in Parkinson's disease research and treatment. Rev Neurosci 30, 709-727.

[162] Vergallo A, Bun RS, Toschi N, Baldacci F, Zetterberg $\mathrm{H}$, Blennow $\mathrm{K}$, Cavedo E, Lamari F, Habert MO, Dubois B, Floris R, Garaci F, Lista S, Hampel $\mathrm{H}$; INSIGHT-preAD study group; Alzheimer Precision Medicine Initiative (APMI) (2018) Association of cerebrospinal fluid $\alpha$-synuclein with total and phospho-tau 181 protein concentrations and brain amyloid load in cognitively normal subjective memory complainers stratified by Alzheimer's disease biomarkers. Alzheimers Dement 14, 1623-1631.

[163] Cussell PJG, Gomez Escalada M, Milton NGN, Paterson AWJ (2020) The N-formyl peptide receptors: Contemporary roles in neuronal function and dysfunction. Neural Regen Res 15, 1191-1198.

[164] Rostami J, Fotaki G, Sirois J, Mzezewa R, Bergström J, Essand M, Healy L, Erlandsson A (2020) Astrocytes have the capacity to act as antigen-presenting cells in the Parkinson's disease brain. J Neuroinflammation 17, 119.

[165] Hirsch EC, Standaert DG Ten (2020) Unsolved questions about neuroinflammation in Parkinson's disease. Mov Disord, doi: 10.1002/mds. 28075

[166] Talbot PJ, ékandé S, Cashman NR, Mounir S, Stewart JN (1993) Neurotropism of human coronavirus 229E. In Coronaviruses: Molecular Biology and Virus-Host Interactions, Laude H, Vautherot J-F, eds. Springer US, Boston, MA, pp. 339-346.

[167] Parham D, Tereba A, Talbot PJ, Jackson DP, Morris VL (1986) Analysis of JHM central nervous system infections in rats. Arch Neurol 43, 702-708.

[168] Kalicharran K, Dales S (1996) The murine coronavirus as a model of trafficking and assembly of viral proteins in neural tissue. Trends Microbiol 4, 264-269.

[169] Arbour N, Talbot PJ (1998) persistent infection of neural cell lines by human coronaviruses. In Coronaviruses and Arteriviruses, Enjuanes L, Siddell SG, Spaan W, eds. Springer US, Boston, MA, pp. 575-581.

[170] Arbour N, Day R, Newcombe J, Talbot PJ (2000) Neuroinvasion by human respiratory coronaviruses. J Virol 74, 8913-8921.

[171] Templeton SP, Perlman S (2007) Pathogenesis of acute and chronic central nervous system infection with variants of mouse hepatitis virus, strain JHM. Immunol Res 39, 160-172.

[172] Jacomy H, St-Jean JR, Brison É, Marceau G, Desforges M, Talbot PJ (2010) Mutations in the spike glycoprotein of human coronavirus OC43 modulate disease in BALB/c mice from encephalitis to flaccid paralysis and demyelination. J Neurovirol 16, 279-293.

[173] Savarin C, Stohlman SA, Hinton DR, Ransohoff RM, Cua DJ, Bergmann CC (2012) IFN- $\gamma$ protects from lethal IL-17 mediated viral encephalomyelitis independent of neutrophils. J Neuroinflammation $\mathbf{9}, 104$.

[174] Weiss SR (2020) Forty years with coronaviruses. J Exp Med 217, e20200537.

[175] Natoli S, Oliveira V, Calabresi P, Maia LF, Pisani A (2020) Does SARS-Cov-2 invade the brain? Transla- 
tional lessons from animal models. Eur J Neurol, doi: 10.1111/ene. 14277

[176] Pillay TS (2020) Gene of the month: The 2019nCoV/SARS-CoV-2 novel coronavirus spike protein. $J$ Clin Pathol 73, 366-369.

[177] Lu W, Maheshwari A, Misiuta I, Fox SE, Chen N, Zigova T, Christensen RD, Calhoun DA (2005) Neutrophilspecific chemokines are produced by astrocytic cells but not by neuronal cells. Brain Res Dev Brain Res 155, 127134.

[178] Hosking MP, Tirotta E, Ransohoff RM, Lane TE (2010) CXCR2 signaling protects oligodendrocytes and restricts demyelination in a mouse model of viral-induced demyelination. PLoS One 5, e11340.

[179] Weinger JG, Marro BS, Hosking MP, Lane TE (2013) The chemokine receptor CXCR 2 and coronavirus-induced neurologic disease. Virology 435, 110-117.

[180] Skinner D, Marro BS, Lane TE (2019) Chemokine CXCL10 and coronavirus-induced neurologic disease. Viral Immunol 32, 25-37.

[181] Berger JR (2020) COVID-19 and the nervous system. $J$ Neurovirol 26, 143-148.

[182] Ahmadpour D, Ahmadpoor P (2020) How the COVID-19 overcomes the battle? An approach to virus structure. Iran J Kidney Dis 14, 167-172.

[183] Rabaan AA, Al-Ahmed SH, Haque S, Sah R, Tiwari R, Malik YS, Dhama K, Yatoo MI, Bonilla-Aldana DK, Rodriguez-Morales (2020) AJ SARS-CoV-2, SARS-CoV, and MERS-CoV: A comparative overview. Infez Med, $\mathbf{2 8 ,}$ 174-184.

[184] Jaimes JA, André NM, Chappie JS, Millet JK, Whittaker GR (2020) Phylogenetic analysis and structural modeling of SARS-CoV-2 spike protein reveals an evolutionary distinct and proteolytically sensitive activation loop. $J \mathrm{Mol}$ Biol 432, 3309-3325.

[185] Meessen-Pinard M, Coupanec AL, Desforges M, Talbot PJ (2017) Pivotal role of receptor-interacting protein kinase 1 and mixed lineage kinase domain-like in neuronal cell death induced by the human neuroinvasive coronavirus OC43. J Virol 91, e01513-e01516.

[186] Tipnis SR, Hooper NM, Hyde R, Karran E, Christie G, Turner AJ (2000) A human homolog of angiotensinconverting enzyme cloning and functional expression as a captopril-insensitive carboxypeptidase. J Biol Chem 275, 33238-33243.

[187] Donoghue M, Hsieh F, Baronas E, Godbout K, Gosselin M, Stagliano N, Donovan M, Woolf B, Robison K, Jeyaseelan R, Breitbart RE, Acton S (2000) A novel angiotensin-converting enzyme-related carboxypeptidase (ACE2) converts angiotensin I to angiotensin 1-9. Circ Res 87, E1-E9.

[188] Li W, Moore MJ, Vasilieva N, Sui J, Wong SK, Berne MA, Somasundaran M, Sullivan JL, Luzuriaga K, Greenough TC, Choe H, Farzan M (2003) Angiotensin-converting enzyme 2 is a functional receptor for the SARS coronavirus. Nature 426, 450-454.

[189] Wong SK, Li W, Moore MJ, Choe H, Farzan M (2004) A 193-amino acid fragment of the SARS coronavirus S protein efficiently binds angiotensin-converting enzyme 2. J Biol Chem 279, 3197-3201.

[190] Clarke NE, Turner AJ (2012) Angiotensin-converting enzyme 2: The first decade. Int J Hypertens 2012, 307315.

[191] Saavedra JM (2020) COVID-19, angiotensin receptor blockers, and the brain. Cell Mol Neurobiol 40, 667-674.
[192] South AM, Diz DI, Chappell MC (2020) COVID-19, ACE2, and the cardiovascular consequences. Am J Physiol Heart Circ Physiol 318, H1084-H1090.

[193] Verdecchia P, Angeli F, Reboldi G (2020) Angiotensinconverting enzyme inhibitors, angiotensin II receptor blockers and coronavirus. J Hypertens 38, 1190-1191.

[194] Gheblawi M, Wang K, Viveiros A, Nguyen Q, Zhong JC, Turner AJ, Raizada MK, Grant MB, Oudit GY (2020) Angiotensin-converting enzyme 2: SARS-CoV-2 receptor and regulator of the renin-angiotensin system. Circ Res 126, 1456-1474.

[195] Wang F, Hou H, Luo Y, Tang G, Wu S, Huang M, Liu W, Zhu Y, Lin Q, Mao L, Fang M, Zhang H, Sun Z (2020) The laboratory tests and host immunity of COVID-19 patients with different severity of illness. JCI Insight 5, e137799.

[196] Touyz RM, Li H, Delles C (2020) ACE2 the Janus-faced protein - from cardiovascular protection to severe acute respiratory syndrome-coronavirus and COVID-19. Clin Sci (Lond) 134, 747-750.

[197] Gallagher PE, Chappell MC, Ferrario CM, Tallant EA (2006) Distinct roles for ANG II and ANG-(1-7) in the regulation of angiotensin-converting enzyme 2 in rat astrocytes. Am J Physiol Cell Physiol 290, C420-C426.

[198] Doobay MF, Talman LS, Obr TD, Tian X, Davisson RL, Lazartigues E (2007) Differential expression of neuronal ACE2 in transgenic mice with overexpression of the brain renin-angiotensin system. Am J Physiol Regul Integr Comp Physiol 292, R373-R381.

[199] Becker LK, Etelvino GM, Walther T, Santos RAS, Campagnole-Santos MJ (2007) Immunofluorescence localization of the receptor Mas in cardiovascular-related areas of the rat brain. Am J Physiol Heart Circ Physiol 293, H1416-H1424.

[200] Freund M, Walther T, von Bohlen und Halbach O (2012) Immunohistochemical localization of the angiotensin-(17) receptor Mas in the murine forebrain. Cell Tissue Res 348, 29-35.

[201] Gironacci MM, Cerniello FM, Longo Carbajosa NA, Goldstein J, Cerrato BD (2014) Protective axis of the renin-angiotensin system in the brain. Clin Sci (Lond), 127, 295-306.

[202] Kehoe PG, Wong S, AL Mulhim N, Palmer LE, Miners JS (2016) Angiotensin-converting enzyme 2 is reduced in Alzheimer's disease in association with increasing amyloid- $\beta$ and tau pathology. Alzheimers Res Therapy $\mathbf{8}$, 50.

[203] Bourgonje AR, Abdulle AE, Timens W, Hillebrands JL, Navis GJ, Gordijn SJ, Bolling MC, Dijkstra G, Voors AA, Osterhaus AD, Voort PH van der, Mulder DJ, Goor H van (2020) Angiotensin-converting enzyme 2 (ACE2), SARS$\mathrm{CoV}-2$ and the pathophysiology of coronavirus disease 2019 (COVID-19). J Pathol 251, 228-248.

[204] Schumacher N, Rose-John S (2019) ADAM17 activity and IL-6 trans-signaling in inflammation and cancer. Cancers (Basel) 11, 1736.

[205] Hsia HE, Tüshaus J, Brummer T, Zheng Y, Scilabra SD, Lichtenthaler SF (2019) Functions of 'A disintegrin and metalloproteases (ADAMs)' in the mammalian nervous system. Cell Mol Life Sci 76, 3055-3081.

[206] Miller AJ, Arnold AC (2019) The renin-angiotensin system in cardiovascular autonomic control: Recent developments and clinical implications. Clin Auton Res 29, 231-243.

[207] Hanff TC, Harhay MO, Brown TS, Cohen JB, Mohareb AM (2020) Is there an association between COVID-19 
mortality and the renin-angiotensin system? A call for epidemiologic investigations. Clin Infect Dis 71, 870-874.

[208] Peña-Silva RA, Chu Yi, Miller Jordan D, Mitchell Ian J, Penninger Josef M, Faraci Frank M, Heistad Donald D (2012) Impact of ACE2 deficiency and oxidative stress on cerebrovascular function with aging. Stroke 43, 33583363.

[209] Baig AM, Khaleeq A, Ali U, Syeda H (2020) Evidence of the COVID-19 virus targeting the CNS: Tissue distribution, host-virus interaction, and proposed neurotropic mechanisms. ACS Chem Neurosci 11, 995-998.

[210] Ziegler CGK, Allon SJ, Nyquist SK, Mbano IM, Miao VN, Tzouanas CN, Cao Y, Yousif AS, Bals J, Hauser BM, Feldman J, Muus C, Wadsworth MH 2nd, Kazer SW, Hughes TK, Doran B, Gatter GJ, Vukovic M, Taliaferro F, Mead BE, Guo Z, Wang JP, Gras D, Plaisant M, Ansari M, Angelidis I, Adler H, Sucre JMS, Taylor CJ, Lin B, Waghray A, Mitsialis V, Dwyer DF, Buchheit KM, Boyce JA, Barrett NA, Laidlaw TM, Carroll SL, Colonna L, Tkachev V, Peterson CW, Yu A, Zheng HB, Gideon HP, Winchell CG, Lin PL, Bingle CD, Snapper SB, Kropski JA, Theis FJ, Schiller HB, Zaragosi LE, Barbry P, Leslie A, Kiem HP, Flynn JL, Fortune SM, Berger B, Finberg RW, Kean LS, Garber M, Schmidt AG, Lingwood D, Shalek AK, Ordovas-Montanes J; HCA Lung Biological Network. Electronic Address: Lungnetqork@humancellatlas; HCA Lung Biological Network (2020) SARS-CoV-2 receptor ACE2 is an interferonstimulated gene in human airway epithelial cells and is detected in specific cell subsets across tissues. Cell 181, 1016-1035.e19.

[211] Strope JD, PharmD CHC, Figg WD (2020) TMPRSS2: Potential biomarker for COVID-19 outcomes. J Clin Pharmacol 60, 801-807.

[212] Gard PR, Rusted JM (2004) Angiotensin and Alzheimer's disease: Therapeutic prospects. Expert Rev Neurother 4, 87-96.

[213] Phillips MI, de Oliveira EM (2008) Brain renin angiotensin in disease. $J$ Mol Med 86, 715-722.

[214] Kehoe PG, Miners S, Love S (2009) Angiotensins in Alzheimer's disease - friend or foe? Trends Neurosci 32, 619-628.

[215] Ohrui, T (2012) [Alzheimer disease-contribution of reninangiotensin system to Alzheimer disease progression]. Nihon Rinsho 70, 1599-1603.

[216] Kaur P, Muthuraman A, Kaur M (2015) The implications of angiotensin-converting enzymes and their modulators in neurodegenerative disorders: Current and future perspectives. ACS Chem Neurosci 6, 508-521.

[217] Wright JW, Harding JW (2010) The brain RAS and Alzheimer's disease. Exp Neurol 223, 326-333.

[218] Wright JW, Harding JW (2019) Contributions by the brain renin-angiotensin system to memory, cognition, and Alzheimer's disease. J Alzheimers Dis 67, 469-480.

[219] Royea J, Zhang L, Tong XK, Hamel E (2017) Angiotensin IV receptors mediate the cognitive and cerebrovascular benefits of losartan in a mouse model of Alzheimer's disease. J Neurosci 37, 5562-5573.

[220] Ribeiro VT, de Souza LC, Simões e Silva AC (2020) Renin-angiotensin system and Alzheimer's disease pathophysiology: From the potential interactions to therapeutic perspectives. Protein Pept Lett 27, 484-511.

[221] Bakhle YS (2020) How ACE inhibitors transformed the renin-angiotensin system. Br J Pharmacol 177, 26572665.
[222] Abo-Youssef A, Khallaf W, Khattab M, Messiha B (2020) The anti-Alzheimer effect of telmisartan in a hyperglycemic ovariectomized rat model; role of central angiotensin and estrogen receptors. Food Chem Toxicol 142, 111441.

[223] Abdelkader N, Abd El-Latif A, Khattab M (2020) Telmisartan/17 $\beta$-estradiol mitigated cognitive deficit in an ovariectomized rat model of Alzheimer's disease: Modulation of ACE1/ACE2 and AT1/AT2 ratio. Life Sci 245, 117388

[224] Barthold D, Joyce G, Brinton RD, Wharton W, Kehoe PG, Zissimopoulos J (2020) Association of combination statin and antihypertensive therapy with reduced Alzheimer's disease and related dementia risk. PLoS One 15, e0229541.

[225] Evans CE, Miners JS, Piva G, Willis CL, Heard DM, Kidd EJ, Good MA, Kehoe PG (2020) ACE2 activation protects against cognitive decline and reduces amyloid pathology in the Tg2576 mouse model of Alzheimer's disease. Acta Neuropathol 139, 485-502.

[226] Walker VM, Davies NM, Martin RM, Kehoe PG (2020) Comparison of antihypertensive drug classes for dementia prevention. Epidemiology, doi: 10.1097/EDE.0000000000001245

[227] Puertas M del C, Martínez-Martos JM, Cobo M, Lorite P, Sandalio RM, Palomeque T, Torres MI, CarreraGonzález MP, Mayas MD, Ramírez-Expósito MJ (2013) Plasma renin-angiotensin system-regulating aminopeptidase activities are modified in early stage Alzheimer's disease and show gender differences but are not related to apolipoprotein E genotype. Exp Gerontol 48, 557-564.

[228] Verdecchia P, Cavallini C, Spanevello A, Angeli F (2020) The pivotal link between ACE2 deficiency and SARSCoV-2 infection. Eur J Intern Med 76, 14-20.

[229] Perrotta F, Matera MG, Cazzola M, Bianco A (2020) Severe respiratory SARS-CoV2 infection: dACE2 receptor matter? Respir Med 168, 105996.

[230] Barillà F, Bassareo PP, Calcaterra G, Romeo F, Mehta JL (2020) Focus on clinical practice: Angiotensin-converting enzyme 2 and corona virus disease 2019: Pathophysiology and clinical implications. J Cardiovasc Med (Hagerstown) 21, 630-633.

[231] Borro M, Di Girolamo P, Gentile G, De Luca O, Preissner R, Marcolong A, Ferracuti S, Simmaco M (2020) Evidence-based considerations exploring relations between SARS-CoV-2 pandemic and air pollution: Involvement of PM2.5-mediated up-regulation of the viral receptor ACE-2. Int J Environ Res Public Health 17, 5573.

[232] Wu X, Nethery RC, Sabath BM, Braun D, Dominici F (2020) Exposure to air pollution and COVID-19 mortality in the United States: A nationwide crosssectional study. MedRxiv 2020.04.05.20054502. doi: 10.1101/2020.04.05.20054502

[233] Kabbani N, Olds JL (2020) Does COVID19 infect the brain? If so, smokers might be at a higher risk. Mol Pharmacol 97, 351-353.

[234] Smith JC, Sausville EL, Girish V, Yuan ML, Vasudevan A, John KM, Sheltzer JM (2020) Cigarette smoke exposure and inflammatory signaling increase the expression of the SARS-CoV-2 receptor ACE2 in the respiratory tract. Dev Cell 53, 514-529.e3.

[235] Jain V, Yuan JM (2020) Predictive symptoms and comorbidities for severe COVID-19 and intensive care unit admission: A systematic review and meta-analysis. Int $J$ Public Health 65, 533-546. 
[236] Usman MS, Siddiqi TJ, Khan MS, Urvish K Patel UK, Shahid I, Ahmed J, Kalra A, Michos ED (2020) Is there a smoker's paradox in COVID-19? BMJ Evid Based Med, doi: 10.1136/bmjemb-2020-111492

[237] Chen T, Wu D, Chen H, Yan W, Yang D, Chen G, Ma K, Xu D, Yu H, Wang H, Wang T, Guo W, Chen J, Ding C, Zhang X, Huang J, Han M, Li S, Luo X, Zhao J, Ning Q (2020) Clinical characteristics of 113 deceased patients with coronavirus disease 2019: Retrospective study. BMJ 368, m1091.

[238] Poyiadji N, Shahin G, Noujaim D, Stone M, Patel S, Griffith B (2020) COVID-19-associated acute hemorrhagic necrotizing encephalopathy: Imaging features. Radiology 296, E119-E120.

[239] Moein ST, Hashemian SMR, Mansourafshar B, KhorramTousi A, Tabarsi P, Doty RL (2020) Smell dysfunction: A biomarker for COVID-19. Int Forum Allergy Rhinol 10, 944-950.

[240] Zens M, Brammertz A, Herpich J, Südkamp N, Hinterseer M (2020) App-based tracking of self-reported COVID-19 symptoms. J Med Internet Res 22, e21956.

[241] De Felice FG, Tovar-Moll F, Moll J, Munoz DP, Ferreira ST (2020) Severe acute respiratory syndrome coronavirus 2 (SARS-CoV-2) and the central nervous system. Trends Neurosci 43, 355-357.

[242] Hainque E, Grabli D (2020) Rapid worsening in Parkinson's disease may hide COVID-19 infection. Parkinsonism Relat Disord 75, 126-127.

[243] Balduino Victorino D, Guimarães-Marques M, Nejm M, Scorza FA, Scorza CA (2020) COVID-19 and Parkinson's disease: Are we dealing with short-term impacts or something worse? J Parkinsons Dis 10, 899-902.

[244] Marreiros R, Müller-Schiffmann A, Trossbach SV, Prikulis I, Hänsch S, Weidtkamp-Peters S, Moreira AR, Sahu S, Soloviev I, Selvarajah S, Lingappa VR, Korth C (2020) Disruption of cellular proteostasis by H1N1 influenza A virus causes $\alpha$-synuclein aggregation. Proc Natl Acad Sci U S A 117, 6741-6751.

[245] Naughton SX, Raval U, Pasinetti GM (2020) Potential novel role of COVID-19 in Alzheimer's disease and preventative mitigation strategies. J Alzheimers Dis 76, 21-25.

[246] Heneka MT, Golenbock D, Latz E, Morgan D, Brown $\mathrm{R}$ (2020) Immediate and long-term consequences of COVID-19 infections for the development of neurological disease. Alzheimers Res Ther 12, 69.

[247] Heneka MT, Kummer MP, Stutz A, Delekate A, Schwartz S, Vieira-Saecker A, Griep A, Axt D, Remus A, Tzeng TC, Gelpi E, Halle A, Korte M, Latz E, Golenbock DT (2013) NLRP3 is activated in Alzheimer's disease and contributes to pathology in APP/PS1 mice. Nature 493, 674-678.

[248] Novellino F, Saccà V, Donato A, Zaffino P, Spadea MF, Vismara M, Arcidiacono B, Malara N, Presta I, Donato G (2020) Innate immunity: A common denominator between neurodegenerative and neuropsychiatric diseases. Int $J$ Mol Sci 21, 1115.

[249] Fathi N, Rezaei N (2020) Lymphopenia in COVID-19: Therapeutic opportunities. Cell Biology Int 44, 1792-1797.

[250] Lega S, Naviglio S, Volpi S, Tommasini A (2020) Recent insight into SARS-CoV2 immunopathology and rationale for potential treatment and preventive strategies in COVID-19. Vaccines (Basel) 8, 224.

[251] Winkler AS, Knauss S, Schmutzhard E, Leonardi M, Padovani A, Abd-Allah F, Charway-Felli A, Emmrich JV, Umapathi T, Satishchandra P, Hoo FK, Dalmau J, Oreja-Guevara C, Ferreira MLB, Pfausler B, Michael BD,
Tagliavini F, Höglinger G, Endres M, Klein C, Hemmer B, Carroll W, Sejvar J, Solomon T (2020) A call for a global COVID-19 Neuro Research Coalition. Lancet Neurol 19, 482-484.

[252] Ferrarese C, Silani V, Priori A, Galimberti S, Agostoni E, Monaco S, Padovani A, Tedeschi G (2020) An Italian multicenter retrospective-prospective observational study on neurological manifestations of COVID-19 (NEUROCOVID). Neurol Sci 41, 1355-1359.

[253] McIntyre RS, Lee Y (2020) Preventing suicide in the context of the COVID-19 pandemic. World Psychiatry 19, 250-251.

[254] McIntyre RS, Lee Y (2020) Projected increases in suicide in Canada as a consequence of COVID-19. Psychiatry Res 290, 113104.

[255] Devitt P (2020) Can we expect an increased suicide rate due to COVID-19? Ir J Psychol Med, doi: 10.1017/ipm.2020.46

[256] Rogers JP, Chesney E, Oliver D, Pollak TA, McGuire P, Fusar-Poli P, Zandi MS, Lewis G, David AS (2020) Psychiatric and neuropsychiatric presentations associated with severe coronavirus infections: A systematic review and meta-analysis with comparison to the COVID-19 pandemic. Lancet Psychiatry 7, 611-627.

[257] Mediouni M, Madiouni R, Kaczor-Urbanowicz KE (2020) COVID-19: How the quarantine could lead to the depreobesity. Obes Med 19, 100255.

[258] Moore RC, Depp CA, Harvey PD, Pinkham AE (2020) Assessing the real-time mental health challenges of COVID-19 in individuals with serious mental illnesses: Protocol for a quantitative study. JMIR Res Protoc 9, e19203.

[259] Dutheil F, Aubert C, Pereira B, Dambrun M, Moustafa F, Mermillod M, Baker JS, Trousselard M, Lesage FX, Navel V (2019) Suicide among physicians and health-care workers: A systematic review and meta-analysis. PLoS One 14, e0226361.

[260] Drapeau C, McIntosh J (2018) U.S.A. suicide 2017: Official final data. Education Faculty Publications.

[261] Sher L (2020) The impact of the COVID-19 pandemic on suicide rates. QJM, doi: 10.1093/qjmed/hcaa202

[262] Lyons D, Frampton M, Naqvi S, Donohoe D, Adams G, Glynn K (2020) Fallout from the COVID-19 pandemic should we prepare for a tsunami of post viral depression? Ir J Psychol Med, doi: 10.1017/ipm.2020.40

[263] Guo Q, Zheng Y, Shi J, Wang J, Li G, Li C, Fromson JA, Xu Y, Liu X, Xu H, Zhang T, Lu Y, Chen X, Hu H, Tang Y, Yang S, Zhou H, Wang X, Chen H, Wang Z, Yang Z (2020) Immediate psychological distress in quarantined patients with COVID-19 and its association with peripheral inflammation: A mixed-method study. Brain Behav Immun 88, 12-27.

[264] Condie LO (2020) Neurotropic mechanisms in COVID19 and their potential influence on neuropsychological outcomes in children. Child Neuropsychol 26, 577-596.

[265] Kaparounaki CK, Patsali ME, Mousa DPV, Papadopoulou EVK, Papadopoulou KKK, Fountoulakis KN (2020) University students' mental health amidst the COVID-19 quarantine in Greece. Psychiatry Res 290, 113111.

[266] Palmer K, Monaco A, Kivipelto M, Onder G, Maggi S, Michel JP, Prieto R, Sykara G, Donde S (2020) The potential long-term impact of the COVID-19 outbreak on patients with non-communicable diseases in Europe: Consequences for healthy ageing. Aging Clin Exp Res 32, 1189-1194. 
[267] Wang MC, Lin FL, Su HH, Kuo PL (2020) Revisiting the relationship between suicide and unemployment in Mexico: Evidence from linear and non-linear co-integration. Front Public Health 8, 60.

[268] IMF, World Economic Outlook Update, June 2020: A Crisis Like No Other, An Uncertain Recovery. https://www.imf.org/en/Publications/WEO/Issues/2020/ 06/24/WEOUpdateJune2020 Accessed July 13, 2020.

[269] Moy V (March 5, 2020) Mexico's Economic Slump Might Last Years. Here's Why. Americas Quarterly. https://www.americasquarterly.org/article/mexicoseconomic-slump-might-last-years-heres-why/

[270] Song J, Li Y, Huang X, Chen Z, Li Y, Liu C, Chen Z, Duan $X$ (2020) Systematic analysis of ACE2 and TMPRSS2 expression in salivary glands reveals underlying transmission mechanism caused by SARS-CoV-2. J Med Virol, doi: 10.1102/jmv.26045

[271] Passarelli PC, Lopez MA, Mastandrea Bonaviri GN, Garcia-Godoy F, D'Addona A (2020) Taste and smell as chemosensory dysfunctions in COVID-19 infection. Am J Dent 33, 135-137.

[272] Stadnytskyi V, Bax CE, Bax A, Anfinrud P (2020) The airborne lifetime of small speech droplets and their potential importance in SARS-CoV-2 transmission. Proc Natl Acad Sci 117, 11875-11877.

[273] Li Y, Ren B, Peng X, Hu T, Li J, Gong T, Tang B, Xu $\mathrm{X}$, Zhou X (2020) Saliva is a non-negligible factor in the spread of COVID-19. Mol Oral Microbiol 35, 141-145.

[274] Giamarellos-Bourboulis EJ, Netea MG, Rovina N, Akinosoglou K, Antoniadou A, Antonakos N, Damoraki G, Gkavogianni T, Adami ME, Katsaounou P, Ntaganou M, Kyriakopoulou M, Dimopoulos G, Koutsodimitropoulos I, Velissaris D, Koufargyris P, Karageorgos A, Katrini K, Lekakis V, Lupse M, Kotsaki A, Renieris G, Theodoulou D, Panou V, Koukaki E, Koulouris N, Gogos C, Koutsoukou A (2020) Complex immune dysregulation in COVID-19 patients with severe respiratory failure. Cell Host Microbe 27, 992-1000.e3.

[275] Kowalski K, Mulak A (2019) Brain-gut-microbiota axis in Alzheimers disease. J Neurogastroenterol Motil 25, 48-60.

[276] Chow AK, Gulbransen BD (2016) Potential roles of enteric glia in bridging neuroimmune communication in the gut. Am J Physiol Gastrointest Liver Physiol 312, G145-G152.

[277] Heiss CN, Olofsson LE (2019) The role of the gut microbiota in development, function and disorders of the central nervous system and the enteric nervous system. JNeuroendocrinol 31, e12684.

[278] Chapelet G, Leclair-Visonneau L, Clairembault T, Neunlist M, Derkinderen P (2019) Can the gut be the missing piece in uncovering PD pathogenesis? Parkinsonism Relat Disord 59, 26-31.

[279] Becker A, Faßbender K, Oertel WH, Unger MM (2019) A punch in the gut - intestinal inflammation links environmental factors to neurodegeneration in Parkinson's disease. Parkinsonism Relat Disord 60, 43-45.

[280] Alexandrov P, Zhao Y, Li W, Lukiw W (2019) Lipopolysaccharide-stimulated, NF-kB-, miRNA-146aand miRNA-155-mediated molecular-genetic communication between the human gastrointestinal tract microbiome and the brain. Folia Neuropathol 57, 211-219.

[281] Agahi A, Hamidi G, Daneshvar R, Hamdieh M, Soheili M, Alinaghipour A, Esmaeili Taba S, Salami M (2018) Does severity of Alzheimer's disease contribute to its respon- siveness to modifying gut microbiota? A double blind clinical trial. Front Neurol 9, 662.

[282] Franceschi F, Ojetti V, Candelli M, Covino M, Cardone S, Potenza A, Simeoni B, Gabrielli M, Sabia L, Gasbarrini G, Lopetuso L, Scaldaferri F, Rossini PM, Gasbarrini A (2019) Microbes and Alzheimer' disease: Lessons from H. pylori and GUT microbiota. Eur Rev Med Pharmacol Sci 23, 426-430.

[283] Doulberis M, Papaefthymiou A, Polyzos SA, Boziki M, Deretzi G, Giartza-Taxidou E, Vardaka E, Grigoriadis N, Katsinelos T, Touloumtzi M, Papanikopoulou K, Anastasiadou K, Georgopoulos S, Dardiotis E, Anastasiadis S, Katsinelos P, Kountouras J (2019) Microbes and Alzheimer's disease: Lessons from H. pylori and GUT microbiota. Eur Rev Med Pharmacol Sci 23, 1845-1846.

[284] Giau VV, Wu SY, Jamerlan A, An SSA, Kim S, Hulme J (2018) Gut microbiota and their neuroinflammatory implications in Alzheimer's disease. Nutrients 10, 1765.

[285] Jiang C, Li G, Huang P, Liu Z, Zhao B (2017) The gut microbiota and Alzheimer's disease. J Alzheimers Dis 58, $1-15$.

[286] Beloqui A, des Rieux A, Préat V (2016) Mechanisms of transport of polymeric and lipidic nanoparticles across the intestinal barrier. Adv Drug Deliv Rev 106, 242-255.

[287] Shakeel M, Jabeen F, Qureshi NA, Fakhr-E-Alam M (2016) Toxic effects of titanium dioxide nanoparticles and titanium dioxide bulk salt in the liver and blood of male sprague-dawley rats assessed by different assays. Biol Trace Elem Res 173, 405-426.

[288] Mackevica A, Olsson ME, Hansen SF (2016) The release of silver nanoparticles from commercial toothbrushes. $J$ Hazard Mater 322, 270-275.

[289] Grissa I, ElGhoul J, Mrimi R, Mir LE, Cheikh HB, Horcajada P (2020) In deep evaluation of the neurotoxicity of orally administered $\mathrm{TiO}_{2}$ nanoparticles. Brain Res Bull 155, 119-128.

[290] Mercier-Bonin M, Despax B, Raynaud P, Houdeau E, Thomas M (2018) Mucus and microbiota as emerging players in gut nanotoxicology: The example of dietary silver and titanium dioxide nanoparticles. Crit Rev Food Sci Nutr 58, 1023-1032.

[291] Gillois K, Lévêque M, Théodorou V, Robert H, MercierBonin M (2018) Mucus: An underestimated gut target for environmental pollutants and food additives. Microorganisms 6, 53.

[292] Ropers MH, Terrisse H, Mercier-Bonin M, Humbert B (2017) Titanium dioxide as food additive. In Application of Titanium Dioxide, Janus M, ed. IntechOpen, doi: 10.5772/intechopen.68883

[293] Sieg H, Braeuning C, Kunz BM, Daher H, Kästner C, Krause BC, Meyer T, Jalili P, Hogeveen K, Böhmert L, Lichtenstein D, Burel A, Chevance S, Jungnickel H, Tentschert J, Laux P, Braeuning A, Gauffre F, Fessard V, Meijer J, Estrela-Lopis I, Thünemann AF, Luch A, Lampen A (2018) Uptake and molecular impact of aluminum-containing nanomaterials on human intestinal caco-2 cells. Nanotoxicology 12, 992-1013.

[294] Turiel-Fernández D, Bettmer J, Montes-Bayón M (2018) Evaluation of the uptake, storage and cell effects of nanoiron in enterocyte-like cell models. J Trace Elem Med Biol 49, 98-104.

[295] Yausheva E, Miroshnikov S, Sizova E (2018) Intestinal microbiome of broiler chickens after use of nanoparticles and metal salts. Environ Sci Pollut Res Int 25, 1810918120. 
[296] Gioria S, Urbán P, Hajduch M, Barboro P, Cabaleiro N, La Spina R, Chassaigne H (2018) Proteomics study of silver nanoparticles on Caco-2 cells. Toxicol In Vitro 50, 347-372.

[297] Amers PMM, Beumer J, van der Vaart J, Knoops K, Puschhof J, Breugem TI, Ravelli RBG, Paul van Schayck J, Mykytyn AZ, Duimel HQ, van Donselaar E, Riesebosch S, Kuijpers HJH, Schipper D, van de Wetering WJ, de Graaf M, Koopmans M, Cuppen E, Peters PJ, Haagmans BL, Clevers H (2020) SARS-CoV-2 productively infects human gut enterocytes. Science 369, 50-54.

[298] Venkatakrishnan AJ, Puranik A, Anand A, Zemmour D, Yao X, Wu X, Chilaka R, Murakowski DK, Standish K, Raghunathan B, Wagner T, Garcia-Rivera E, Solomon H, Garg A, Barve R, Anyanwu-Ofili A, Khan N, Soundararajan V (2020) Knowledge synthesis from 100 million biomedical documents augments the deep expression profiling of coronavirus receptors. Elife 9, e58040.

[299] Chen Y, Chen L, Deng Q, Zhang G, Wu K, Ni L, Yang Y, Liu B, Wang W, Wei C, Yang J, Ye G, Cheng Z (2020) The presence of SARS-CoV-2 RNA in the feces of COVID-19 patients. J Med Virol 92, 833-840.

[300] Gupta S, Parker J, Smits S, Underwood J, Dolwani S (2020) Persistent viral shedding of SARS-CoV-2 in feces - a rapid review. Colorectal Dis 22, 611-620.

[301] Smyk W, Janik MK, Portincasa P, Milkiewicz P, Lammert F, Krawczyk M (2020) COVID-19: Focus on the lungs but do not forget the gastrointestinal tract. Eur J Clin Invest 50, e13276.

[302] Orive G, Lertxundi U, Barcelo D (2020) Sci Total Environ 732, 139298.

[303] Castro-Rosas J, Cerna-Cortés JF, Méndez-Reyes E, Lopez-Hernandez D, Gómez-Aldapa CA, Estrada-Garcia T (2012) Presence of faecal coliforms, Escherichia coli and diarrheagenic E. coli pathotypes in ready-to-eat salads, from an area where crops are irrigated with untreated sewage water. Int J Food Microbiol 156, 176-180.

[304] Jain A (2020) COVID-19 and lung pathology. Indian J Pathol Microbiol 63, 171-172.

[305] Puisney C, Baeza-Squiban A, Boland S (2018) Mechanisms of uptake and translocation of nanomaterials in the lung. In Cellular and Molecular Toxicology of Nanoparticles, Saquib Q, Faisal M, Al-Khedhairy AA, Alatar AA, eds. Springer International Publishing, Cham, pp. 21-36.

[306] Yousef MI, Abuzreda AA, Kamel MAN (2019) Cardiotoxicity and lung toxicity in male rats induced by long-term exposure to iron oxide and silver nanoparticles. Exp Ther Med 18, 4329-4339.

[307] Calderón-Garcidueñas L, Franco-Lira M, Torres-Jardón R, Henriquez-Roldán C, Barragán-Mejía G, ValenciaSalazar G, Gonzaléz-Maciel A, Reynoso-Robles R, Villarreal-Calderón R, Reed W (2007) Pediatric respiratory and systemic effects of chronic air pollution exposure: Nose, lung, heart, and brain pathology. Toxicol Pathol 35, 154-162.

[308] Bello-Chavolla OY, Bahena-Lopez JP, Antonio-Villa NE, Vargas-Vázquez A, González-Díaz A, Márquez-Salinas A, Fermín-Martínez CA, Naveja JJ, Aguilar-Salinas CA (2020) Predicting mortality due to SARS-CoV-2: A mechanistic score relating obesity and diabetes to COVID-19 outcomes in Mexico. J Clin Endocrinol Metab 105, dgaa346.

[309] Hernández H (2020) Mortalidad por covid-19 en México. Notas preliminares para un perfil sociodemográfico. Notas de coyuntura del crim No. 36, México, crim-unam, pp. 7.
[310] Romero Zavala M, Despeghel L (2020) ¿Qué nos dicen las actas de defunción de la CDMX? Nexos, https://datos.nexos.com.mx/?p=1388

[311] Calderón-Garcidueñas L, Mora-Tiscareño A, Ontiveros E, Gómez-Garza G, Barragán-Mejía G, Broadway J, Chapman S, Valencia-Salazar G, Jewells V, Maronpot RR, Henríquez-Roldán C, Pérez-Guillé B, Torres-Jardón R, Herrit L, Brooks D, Osnaya-Brizuela N, Monroy ME, González-Maciel A, Reynoso-Robles R, VillarrealCalderon R, Solt AC, Engle RW (2008) Air pollution, cognitive deficits and brain abnormalities: A pilot study with children and dogs. Brain Cogn 68, 117-127.

[312] Calderón-Garcidueñas L, D'Angiulli A, Kulesza RJ, Torres-Jardón R, Osnaya N, Romero L, Keefe S, Herritt L, Brooks DM, Avila-Ramirez J, Delgado-Chávez R, Medina-Cortina H, González-González LO (2011) Air pollution is associated with brainstem auditory nuclei pathology and delayed brainstem auditory evoked potentials. Int J Dev Neurosci 29, 365-375.

[313] Calderón-Garcidueñas L, Engle R, Mora-Tiscareño A, Styner M, Gómez-Garza G, Zhu H, Jewells V, TorresJardón R, Romero L, Monroy-Acosta ME, Bryant C, González-González LO, Medina-Cortina H, D’Angiulli A (2011) Exposure to severe urban air pollution influences cognitive outcomes, brain volume and systemic inflammation in clinically healthy children. Brain Cogn 77, 345-355.

[314] Calderón-Garcidueñas L, Mora-Tiscareño A, MeloSánchez G, Rodríguez-Díaz J, Torres-Jardón R, Styner M, Mukherjee PS, Lin W, Jewells V (2015) A critical proton MR spectroscopy marker of Alzheimer's disease early neurodegenerative change: Low hippocampal NAA/Cr ratio impacts $\mathrm{APOE} \varepsilon 4$ Mexico City children and their parents. J Alzheimers Dis 48, 1065-1075.

[315] Calderón-Garcidueñas L, Mora-Tiscareño A, Franco-Lira M, Zhu H, Lu Z, Solorio E, Torres-Jardón R, D’Angiulli A (2015) Decreases in short term memory, IQ, and altered brain metabolic ratios in urban Apolipoprotein $\varepsilon 4$ children exposed to air pollution. J Alzheimers Dis 45, 757-770.

[316] Calderón-Garcidueñas L, Jewells V, Galaz-Montoya C, van Zundert B, Pérez-Calatayud A, Ascencio-Ferrel E, Valencia-Salazar G, Sandoval-Cano M, Carlos E, Solorio E, Acuña-Ayala H, Torres-Jardón R, D’Angiulli A (2016) Interactive and additive influences of gender, BMI and Apolipoprotein 4 on cognition in children chronically exposed to high concentrations of PM2.5 and ozone. APOE 4 females are at highest risk in Mexico City. Environ Res 150, 411-422.

[317] Calderón-Garcidueñas L, de la Monte SM (2017) Apolipoprotein E4, gender, body mass index, inflammation, insulin resistance, and air pollution interactions: Recipe for Alzheimer's disease development in Mexico City young females. J Alzheimers Dis 58, 613-630.

[318] Calderón-Garcidueñas L, Mukherjee PS, Kulesza RJ, Torres-Jardón R, Hernández-Luna J, Ávila-Cervantes R, Macías-Escobedo E, González-González O, GonzálezMaciel A, García-Hernández K, Hernández-Castillo A, Villarreal-Ríos R; Research Universidad del Valle de México UVM Group (2019) Mild cognitive impairment and dementia involving multiple cognitive domains in Mexican urbanites. J Alzheimers Dis 68, 1113-1123.

[319] Calderón-Garcidueñas L, Kulesza RJ, Mansour Y, AielloMora M, Mukherjee PS, González-González LO (2019) Increased gain in the auditory pathway, Alzheimer's disease continuum, and air pollution: Peripheral and central 
auditory system dysfunction evolves across pediatric and adult urbanites. J Alzheimers Dis 70, 1275-1286.

[320] Calderón-Garcidueñas L, Herrera-Soto A, Jury N, Maher BA, González-Maciel A, Reynoso-Robles R, RuizRudolph P, van Zundert B, Varela-Nallar L (2020) Reduced repressive epigenetic marks, increased DNA damage and Alzheimer's disease hallmarks in the brain of humans and mice exposed to particulate urban air pollution. Environ Res 183, 109226.

[321] Calderón-Garcidueñas L, Torres-Jardón R, Kulesza RJ, Mansour Y, González-González LO, Gónzalez-Maciel A, Reynoso-Robles R, Mukherjee PS (2020) Alzheimer disease starts in childhood in polluted Metropolitan Mexico City. A major health crisis in progress. Environ Res 183, 109137.

[322] Babiloni C, Blinowska K, Bonanni L, Cichocki A, De Haan W, Del Percio C, Dubois B, Escudero J, Fernández A, Frisoni G, Guntekin B, Hajos M, Hampel H, Ifeachor
E, Kilborn K, Kumar S, Johnsen K, Johannsson M, Jeong J, LeBeau F, Lizio R, Lopes da Silva F, Maestú F, McGeown WJ, McKeith I, Moretti DV, Nobili F, Olichney J, Onofrj M, Palop JJ, Rowan M, Stocchi F, Struzik ZM, Tanila H, Teipel S, Taylor JP, Weiergräber M, Yener G, Young-Pearse T, Drinkenburg WH, Randall F (2020) What electrophysiology tells us about Alzheimer's disease: A window into the synchronization and connectivity of brain neurons. Neurobiol Aging 85, 58-73.

[323] Stefi AL, Margaritis LH, Skouroliakou AS, Vassilacopoulou D (2019) Mobile phone electromagnetic radiation affects Amyloid precursor protein and $\alpha$ synuclein metabolism in SH-SY5Y cells. Pathophysiology 26, 203-212.

[324] Bandara P, Carpenter DO (2018) Planetary electromagnetic pollution: It is time to assess its impact. Lancet Planet Health 2, e512-e514. 